\title{
Coptic Burial Wrapping
}

\author{
Jonathan P. Elias
}

"Bandages of fine linen cloth, smeared over with gum"- how frequent is the refrain and how quintessentially Egyptian. However, the Herodotean account of Egyptian embalming (The Persian Wars Book II, 86) is quoted so often as to almost disguise its own significance. Of the three embalming standards Herodotus addresses, only his "most perfect" one includes wrapping as part of the service. Furthermore, Herodotus leaves us with the distinct impression that wrapping is as basic as evisceration and embalming to really approaching the "manner" of Osiris and that only by providing a decent wrapping job will one have a shot at practical preservation and ritual conquest of oblivion. ${ }^{1}$ To the extent that this properly represents an ongoing ancient Egyptian tradition and not just one current around $440 \mathrm{BCE}$, what effect would such ideas have on funerary wrapping in the Christian era and at Naga ed-Deir in particular? ${ }^{2}$

In speaking about Christian funerary behavior, there is a tendency to refer to earlier traditions as "pagan" as if there had been a clean break with all ancient rites once monotheism was adopted. The notion of a "clean break" associated with new religious sensibilities is misleading and in view of the difficulty in recognizing the practices of "Early Christianity" archaeologically inside Egypt, it will be preferable to discuss wrapping methods at Naga ed-Deir in a stylistic or methodological way, and simply say "Coptic Egyptian" when referring to wrapped bodies prepared under the Byzantine hegemony. ${ }^{3}$ In view of the complex array of wrapping methods, there is clearly a need to understand

1 Herodotus in the original passage respects Osiris by not naming him.

2 In the Byzantine period, Naga ed-Deir developed as a village and cemetery area immediately northwest of the Coptic monastery known as Deir el-Malak (Deir el-Melac in older sources). A large wadi, the southernmost of three cutting through the ancient cemeteries (Wadi 3) limited village expansion to the north, while the area south of the village, Reisner noted, served the Coptic community of Girga as burial ground (Reisner 1908, 2). The city of Girga, of course, lies immediately southwest of Naga ed-Deir and on the opposite (west) side of the Nile. Cemetery N 2000/N 2500 is well north of the village astride the mouth of the middle wadi (Wadi 2). The Coptic interments occur amidst those of far earlier times. A long historical association of Naga ed-Deir and Girga is likely.

3 On the difficulty of discerning "Early Christianity" in the archaeological record in Egypt, see Bagnall $(1988 ; 1993,279)$. Regarding the stylistic or methodical approach of this chapter, compare the division of Roman Period mummies into ten types, presented by Petrie $(1911,3)$.

(C) JONATHAN P. ELIAS, 2021 | DOI:10.1163/9789004396906_013

This is an open access chapter distributed under the terms of the CC BY-NC-ND4.olicense. 
Coptic Egyptian wrapping as distinct from other modes associated with late antiquity, such as "red shroud" compositions, produced before CE 180 when the Roman Empire was at its most affluent, and rhombic (diagonal lozenge) "builds" largely datable to before CE 230, after which time the Empire's fiscal and administrative problems mounted. ${ }^{4}$

Under a wealthy and cosmopolitan Empire eager for novelty, experimentation in funerary expression took off. Egypt was by this time part of the broader Mediterranean world and was subject to artistic influences from a wide area; Hellenism and the realistic aesthetic of the Faiyum mummy portrait had grown to be popular in the northern part of the country. ${ }^{5}$ Egyptian abhorrence of foreign practices, referred to by Herodotus (The Persian Wars Book II, 91) had relaxed enormously. Thick mud-plaster "cartonnage" mummy cases expressing Hellenistic tunics and togas sculpturally came into production alongside the more traditional masks and flat plaque ensembles of plastered linen. The art of the painted linen shroud became similarly subdivided; those showing the deceased clothed elegantly in fine linen mantles holding the requisite cup

As an aside, similar caution is suggested in using the term "Greco-Roman" to describe mummies. Greco-Roman is a loose time period, not a style of mummification. Nor should the term be used to insinuate that the culture was being watered down, as much as it was simply beginning to change in different parts of Egypt. For instance, mummification in the way it was practiced in the Ptolemaic period was widely disparaged by Smith and Dawson (1924), as being a pale reflection of earlier methodologies. This is really not very accurate, as the Ptolemaic Period saw rather careful adherence in certain communities to the methods of so-called "classic mummification," close to what Herodotus described as "the most expensive method" in his day (44O BCE).

4 The red shroud mummy of Artemidorus (British Museum EA 21810) is dated by the hair styling of his portrait to 100-120 CE, the time of Trajan (Taylor 2001, 89, fig. $5^{2}$ ).

Rhombic bandaging is Petrie's term for the crisscrossing of bandages into lozenge-shaped coffers, often embellished with a gilt stud. Other terms suggested for this form of bandaging include "coffered" or "diagonal lozenge webbing." It is itself "traditional" insofar as the lozenge pattern is not a Hellenistic innovation, but occurred in various types of bead net shrouds manufactured from the Third Intermediate Period to Ptolemaic times. We note at least some of the portraits associated with lozenge-webbed mummies have been attributed to the aesthetic of the Empire under Caracalla (198-217 CE), like Mummy Berlin SMPK Ägyptisches Museum 11673 (Willeitner 1998, 320, fig. 61).

5 The naturalistic portrait panels (encaustic paintings on wooden board) are positioned upon the face of mummies of both the red shroud and rhombic bandage types. Many of the panels were long ago separated from the bodies they adorned, so we do not often know which wrapping pattern they accompanied, but panel-painting is believed to continue into the second half of the fourth century (Parlasca, 1997, 129). Opinion remains divided as to whether the painting was done on these panels specifically for a funerary purpose (Parlasca 1997, 127). Portraits were surely done also upon shrouds, and some of these are used by persons devoted to the cult of Serapis (Riggs 2005, 231). 
and garland of rosebuds and myrtle, are so-designed as to reduce the image of Osiris to a mere doll, while protective deities and $b a$-birds are pushed to the sides; on others, Osiris or Hathor are still the main event. ${ }^{6}$ The red shroud mummies combine two different systems: the face is a naturalistic Faiyumic portrait, while from the shoulders down, traditional symbols and motifs are arranged in ways reminding us of anthropoid coffins of 675 вСE. ${ }^{7}$ Under the tolerance of cosmopolitan Hellenism, traditions that varied from each other in specific ways merged with each other and were folded in again with Egyptian ones in syncretism. ${ }^{8}$ Process-wise, the era is extremely interesting and still not fully understood. What can be said is that under an economically stressed, significantly weakened Empire ruled from Byzantium, there was a receding of sumptuous funerary expression.

\section{1 \\ Interplay of Traditions}

In Egypt, there was considerable variation in thoroughness of mummification long before Christianity had become something tolerated under Constantine $(313 \mathrm{CE})$ and had been elevated to the state religion under emperor Theodosius (346-395 CE). ${ }^{9}$ Mummification persisted during this era, but the degree of adherence to so-called "classic" mummification, with its emphasis on evisceration, natron-desiccation, aromatic spicing, and elaborate wrapping, may be presumed to have varied widely within and between communities. ${ }^{10}$ By

6 Bresciani 1996.

7 See, for example, Cairo CG 33219, of 100-125 CE. The paintings on this red shroud mummy are organized into traditional horizontal registers like those found on earlier coffins. It is described by Corcoran $(1997,47)$ and shown in her plate 5 . Similar organization and motifs are seen in the red shroud mummy of Artemidorus, dated to the same period (note 4). Mention should be made of Terenuthis (the western Delta site of Kom Abu Billo) where the funerary stelae associated with Christians often include images of a dog (Anubis) and a bird (Horus) as companions to the deceased lying supine on a bed. See Willeitner (1998, 317 , fig. 56). Palmyrene embalming may have had an effect on Egypt, particularly during the period of administrative joining in the era of Odenathus and Zenobia at the end of the third century. Palmyra emerged as a silk-using and even a silk-producing locus, and mummies of Palmyrene origin (rarities, as only four are known) show use of silk in the wrapping (Gk. óroonpıxós) to a larger extent than Egyptian mummies (Girotti et al. 2005, 263).

$9 \quad$ For example, a sizeable proportion of the so-called golden mummies of Bahariya (c. end of the first century ВСЕ) are generally laid to rest without sufficient desiccation. Resin is liberally used but to little effect as a body preservative (Ikram 2015, 20).

10 The consensus view is that some "form of mummification" survived until the sixth century (Heikkinen 2012, 107). 
$392 \mathrm{CE}$, such practices were under enormous pressure. ${ }^{11}$ We can assume that the people of Naga ed-Deir, located not so far south of the White Monastery (Deir el-Abyad, north of Sohag), would have been particularly hard-pressed to reject the "errors" of traditional mummification as admonished by its abbot Shenoute (fl. 430-46o CE) who regularly assailed whatever non-Christian monuments still stood in the region of Akhmim, in Panopolis proper, and at Atripe (Athribis) on the west bank, opposite. ${ }^{12}$

Budge commented on the essential difference between pre-Christian Egyptian and Christian Egyptian attitudes regarding the necessity of mummifying dead bodies: "The Egyptian embalmed his dead because he believed that the perfect soul would return to the body after death and would inhabit it once more; he therefore took pains to preserve it from all destroying influences. The Christian believed that Christ would give him back his body changed and incorruptible, and that it was therefore unnecessary for him to preserve it with spices and drugs."13 In a toned-down way, this remark conveys the feelings of St. Augustine (354-430 CE) who pointed out that body preservation has nothing to do with Christian goals, for these have at their heart the immortality of the soul. ${ }^{14}$ At the same time, Christians held the Old Testament figures in high esteem, and the tradition surrounding the burial of patriarchs Jacob and Joseph treated embalming, and specifically that done in the Egyptian manner, as a keen demonstration of respect. ${ }^{15}$ Similarly, and in reference to such Old Testament archetypes, the infant Jesus receives frankincense and myrrh from the Magi, as a sign of burial. He appears tightly swaddled and mummylike on the day of his birth as a sign to the shepherds of his future, in which he transacts death and achieves life eternal. Regarding a demonstrably late Roman mummy in Montreal, whose preparation (dated through radiocarbon) occurred within the period 200 to $400 \mathrm{CE}$, the body was eviscerated and

$11392 \mathrm{CE}$ is the moment of sea change. The placement of mummies within domestic structures was outlawed by Theodosius in that year (Willeitner 1998, 320). Lösch, Hower-Tillman, and Zink (2013,36), accounting for the discovery of bituminous matter in some bodies buried at the Coptic era site of Deir el-Bachit, point out that mummification itself was not specifically banned in Theodosian decrees.

12 Schulz 1998, 491. Shenoute is given an unconfirmed lifespan of 118 years (348-466 CE). He attended the Council of Ephesus (Ad. 431). He established the monastery around $440 \mathrm{CE}$ and was present at the Council of Chalecedon $\left(45^{1} \mathrm{CE}\right)$.

13 Budge 1894, 188.

14 Leca [1976] 1981, 251.

15 Genesis 50:3, where Joseph prepared Jacob's body for burial, contains the tradition of the forty days allotted for embalming; three score and ten days total for mourning. 
received incision plates clearly intended to align with older ideas. ${ }^{16}$ The application of linen cloth around this mummy is voluminous, with use of outer investing layers tied down by ribbon-width bandages crisscrossing the body. The modality aligns with far older methods, showing that classic mummification was obtainable in a period when Christian communities were expanding throughout Egypt. ${ }^{17}$

Mummification of the "classic" type falls away after the late fourth century, but salt is a frequent addition to burials in Coptic Egypt, and its use was intended to help preserve non-eviscerated bodies for a time after burial while they underwent decomposition. Along with sand and hot sun, such deliberate buffering may allow Coptic bodies to reach preservation states describable as "assisted natural mummification."18 A good example of such a mummy is the so-called "Embroiderer," a Coptic woman found at el-Sheikh Ibada (Antinoë), excavated by Albert Gayet $\left(1895^{-1910)}\right)^{19}$ The fact is that "mummies" of this type show the ways in which Coptic funerary preparation differs considerably from that of pharaonic times. The woman is not "wrapped" in bandages; rather, she was "clothed" in three dresses and a cap. With regard to the use of other embalming substances by the Copts, new studies are surprising. A "black mummy", having skin treated externally with resin (bitumen), has been confirmed recently as being Coptic in date, and while somewhat unusual, it is not an isolated case. ${ }^{20}$

As far as fabric usage in the Coptic Egyptian burials at Naga ed-Deir is concerned, bodies are initially dressed or have draped around them normal articles of clothing. In what were early medieval survivals of traditional processing, they are sometimes provided with supportive backboards of wood or

16 Redpath Museum (RM2717): its linen is radiocarbon dated to the interval 230-380 CE (Wade et al. 2014, 106).

17 At Akhmim, for example, just north of Naga ed-Deir, the Christian population was substantial already in the late third century (McNally and Dvoržak Schrunk 1993, 5).

18 This specifically Coptic variant of mummification is seen in many burials at Naga ed-Deir, but is found in many other sites as well, for example, at el-Hibeh, farther north in Middle Egypt (Heikkinen 2012, 107-116).

19 Brussels RMAH Inv. Nr 1045 (Pommerening 2010, 88, fig. 14).

20 This "black mummy" is the so-called "Mummy of a woman with a baby" (Museum of Confluences, Lyon Inv. goo2977 A). The hair of this person (sample Lyon6) is dated to $1270+/-30$ yr. and $1275+/-30$ yr. BP, putting her into the seventh century CE (Richardin et al. 2013, 349).

A "bitumen-like substance" has also been identified in the lung tissue, intervertebral spaces, and abdomen of damaged mummies discovered in the necropolis associated with the Coptic monastery at Deir el-Bachit, at Dra Abu el-Naga, Thebes (Lösch, Hower-Tillman, and Zink 2013, 31). 


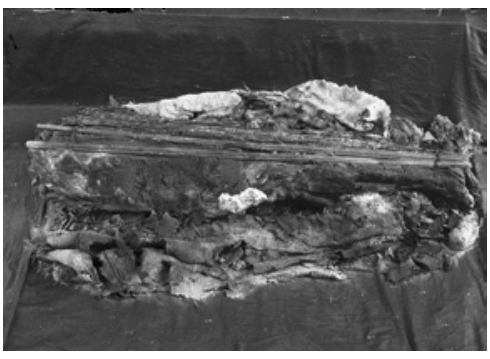

FIGURE 11.1A

Body from $\mathrm{N} 2004$ turned over showing supporting struts (a "litter") and caked salt (NED-B-7888)

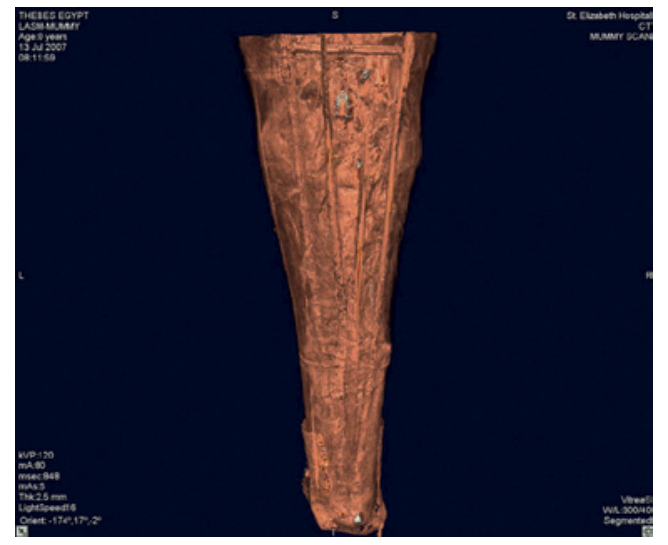

FIGURE 11.1B

A mummy with supportive struts, Late Ptolemaic Period, probably from Thebes LASM Inv. MG 64.1.1a. Baton Rouge, Louisiana

travois-like litters of sticks (of species: "sunt", Acacia nilotica, palm, Phoenix dactylifera L., Sesaban, Sesbania aegyptiaca) often tied together, intended to keep limbs and trunk articulated during transport. ${ }^{21}$ This core is then enveloped protectively by so-called "wrapping shawls" of linen varying in fineness, and frequently (but not always) with shawls of "sackcloth" used on the outside. (See Fig. 11.1a and historical precedent, Fig. 11.1b.)

The expectation that a dead body should be embalmed and wrapped has influenced scriptural tradition and has even wormed its way into iconography to influence and sometimes confuse our impressions of how Christian

21 The term "litter" is used by Yohe, Gardner and Heikkinen (2005) to describe these constructions. They are not new to the Coptic period and are noted in burials of the Late Ptolemaic and Early Roman eras. One of these litter-constructions was found intact in a mummy of Late Ptolemaic date in Baton Rouge, Louisiana, scanned by the Akhmim Mummy Studies Consortium and Louisiana State Art Museum in 2007 (LASM Inv. MG 64.1.1.a; Elias 2007, 11, fig. 22). 
bodies looked when fully prepared for burial. ${ }^{22}$ Engraved renderings of those mummies entering early European cabinets of curiosity (wunderkammern) emphasized their often elaborate bandaging and have taught us to expect all mummies to be more or less systematically wrapped in narrow gauge strips. Although much of this content pertained to Dynastic mummies, some mummies of the later periods were also illustrated. A good example is the famous figure of a Roman Period mummy drawn by G. B. Balatri in 1647 to illustrate Giovanni Nardi's commentary to Book 6 of Lucretius's De Rerum Natura. ${ }^{23}$ Its limbs are entwined within a tight herringbone pattern of the kind created by repeated figure-of-eight bandaging turns (Fig. 11.2, upper). This wrapped figure with its bizarre encaged head was so impressive that it was carried over into many later publications. These included Willem Goeree's Jewish Antiquities (169o) and the early eighteenth century treatise on embalming, Thomas Greenhill's Nekpokēdeia (1705). ${ }^{24}$ It even appears in Jacob Scheuchzer's series on Biblically relevant plant species (1731), where it accompanies a fanciful scene showing the embalming of Jacob. ${ }^{25}$ It has become iconic. Similarly, a late child mummy shown in van den Aveele's plate from Goeree's publication (Fig. 11.2, lower) is depicted with wide spiral bandages that want to suggest a swaddled baby Jesus. Spiral work is also the choice of the Mennonite mystic and artist Jan Luyken who shows in his illustration of Lazarus newly raised from death (Fig. 11.3a) tightly wound by ribbon-width bandages, which Christ's voice is coaxing to unwind. ${ }^{26}$

22 An interesting example is found on a gold relief in the Louvre. It contains a depiction of Jesus's sudarium floating above a diagonally crisscrossing assemblage of struts or bandages. It dates to the tenth century (Reber, 1893, 113, fig. 65).

23 Giovanni Nardi (1580-1655), a Florentine physician, collected Egyptian antiquities. Artist Giovan Batista Balatri was engaged by Nardi to draw elements of his collection to illustrate his commentary on De rerum Natura, by the Roman atomist philosopher Lucretius (Nardius 1647). The mummies appeared in plate 4 of that work. See the illuminating article by Śliwa $(2006,256)$. The illustration was also reproduced in Pollès $(2001,49)$.

24 Willem Goeree of Amsterdam, publisher of Biblical treatises (1635-1711). Joodsche Oudheden, ofte voor-bereidselen tot de bybelsche wysheid (Jewish Antiquities, or Introduction into Biblical Wisdom) is the alternative title of the Goeree's Voor-bereidselen tot de Bybelsche wysheid, en gebruik der heilige en kerklijke historien, (Introduction into Biblical Wisdom and the Use of the Holy and Ecclesiastical Histories) published in Amsterdam in 169o. Balatri's original plate was redrawn and engraved by the Dutch artist Jan van den Aveele (1655-1722).

25 J. Scheuchzer, Physica Sacra, 1731, Tab. 119, entitled: Iacobus aromate conditus, an illustration of the text of Genesis chapter 50, 2-3, which is set in a European anatomical theatre, shows Nardi's mummy hanging next to the frame of the print.

26 The relevant passage is John 11:44. Even images of Jewish bodies appearing in illustrations of the Enlightenment period emphasize spiral bandaging, for example, those in Calmet ([1722] 1732, 66o). 


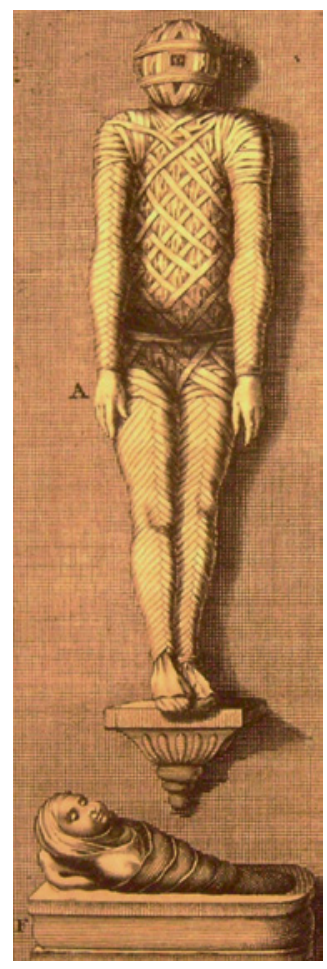

FIGURE 11.2

Mummies by van den Aveele (original Figs. $1 \mathrm{~A}, 1 \mathrm{~F}$ )

The net effect of this type of imagery is to further complicate our ideas regarding how Christian funerary behavior emerged as something distinct from overlapping Hellenistic traditions. We are reminded that the Coptic wrapping modes actually encountered in late cemeteries like Naga ed-Deir N 2000/N 2500 are rather distinct, as well they should be, since they represent strategies used five hundred years after many of those associated with late antiquity. ${ }^{27}$ One of the few wrapped bodies in an early collection whose treatment is remotely suggestive of Coptic methods is the "mummy on the plinth" (Fig. 11.3b) in the

27 Within the context of Byzantine culture, Copts were monophysite Christians (Eutychians or Jacobites) believing that Christ had one nature, divine. This faith was rejected by mainstream Orthodoxy at the Council of Chalcedon in favor of the doctrine that Christ has two natures, human and divine. Coptic beliefs are to be distinguished from those of Melkites, "royalists" loyal to the Emperor Marcian, who upheld the strictures of the Council of Chalcedon. The seventh century CE saw both persecution of the Copts and attempts by the emperor to heal the schism through compromises. These were unsuccessful, and the Coptic Church maintained an adversarial position with regard to Orthodoxy and enmity toward the policies of Constantinople. The Arab conquest of Egypt was simplified as a result (Bell [1948] 1980, 116). 


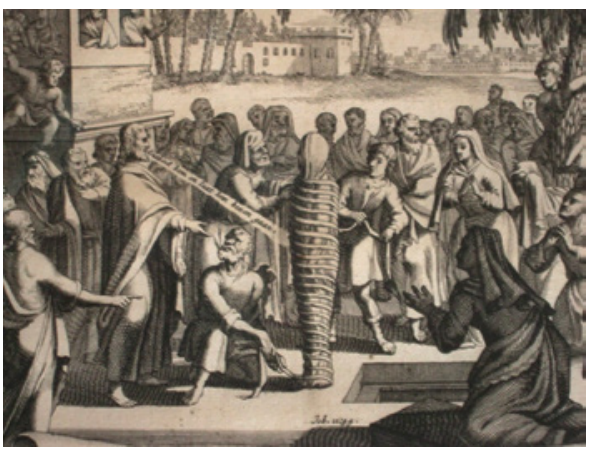

FIGURE 11.3A

Jan Luyken, Lazarus raised from the dead, a work of 1690

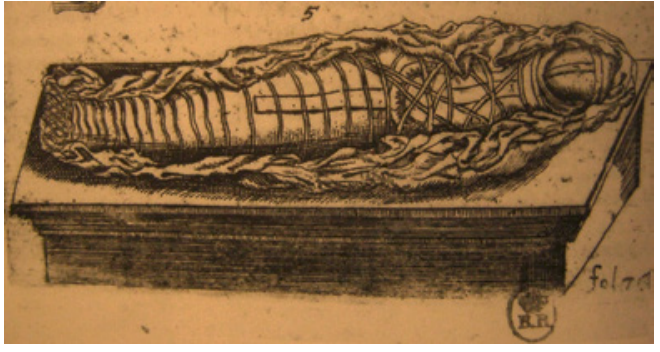

FIGURE 11.3B

Mummy owned by Duke Friedrich III of Holstein-Gottorp shown in Olearius's Gottorffische Kunstkammer (1674)

collection of Duke Friedrich III of Holstein-Gottorp in Schleswig shown in Olearius's Gottorffische Kunstkammer. ${ }^{28}$

\section{$3 \quad$ Wrapping Methods of Earlier Times}

Pre-Coptic mummy wrapping approaches varied greatly, but generally utilized linen bandages in such a way as to form complex overlapped winding layers of narrow bandages that tend to be overrun by larger textile pieces investing the windings, topped by some type of shroud. Winding methods of various sorts are discernible in ancient Egyptian mummies, but too seldom described. Nevertheless, the principles basic to the work are part of all bandaging, not just that which is ancient Egyptian. ${ }^{29}$ Essentially, a starter point at the tip of the initial bandage is held down, presumably by fingers of the left hand, while

28 Olearius 1674, Tab. 36, no. 5, shown in Germer $(1997,104)$. It is also reproduced in Pollès $(2001,52)$.

29 An established terminology can be found in Bureau of Medicine and Surgery, Handbook of the Hospital Corps United States Navy 1939, Washington DC, Govt. Printing Office, 1939 (revised from 1930). 
the right hand holds the active bandage (known as a roller) and circles the circumference of the body part with sustained tension so as to be superimposed on the preceding layer. So-called "initial turns" are crucial to protect against slippage. In "good bandaging," the exposed part of each underlying bandage should be kept equal. This is done by laying the lower edge of the active roller over an imaginary center line in the bandage previously laid down.

Conservator Mimi Leveque has done some interesting research on wrapping as part of her various conservation projects on Egyptian mummies. For example, in research performed on a Twenty-first Dynasty mummy, Leveque found "six principle layers" consisting of fabrics of different grades varying in fineness of weave used at differing elevations in the mummy bundle. ${ }^{30}$ The innermost wrapping layer (A) was not very easily understood, but included bandages varying from 10.0 to $15.5 \mathrm{~cm}$ in width. The head was involved in this early stage. In the next stage (B), the bandages covering it were secured by thin "straps" (12-13 mm wide) that essentially crisscrossed the zone above the shoulders, while wadded scraps of linen (crudely folded) were positioned lower down to fill voids between limbs. This wadding was particularly concentrated on the abdomen to help support overlying layers describable as spiral (or "diagonal") windings (layers C and D). The bandages in the more inward of these windings (C) were finely woven stuff, approx. 27.0 to $28.0 \mathrm{~cm}$ (11 inches) wide. At one point, retaining straps had been arranged vertically as a tie-down to keep the spirally wound bandages in place, and also kept a fringed bundle in place on the mummy's abdomen. In layer D, bandages of coarsely woven linen were applied spirally. Layer E consisted of a "very large" piece of "loosely woven fabric" $152.5 \mathrm{~cm}$ across, which had been so-folded as to produce a four-layer pad that was also wound around the body spirally. G. Elliot Smith describes the folding of a large sheet to produce a multi-layer covering by the Twenty-first Dynasty priests who restored the mummy of Siptah. ${ }^{31}$

Christian Innovations in Body Preservation and Wrapping Methodology

An examination of over ninety burials from the Coptic cemetery Naga ed-Deir $\mathrm{N} 2000 / \mathrm{N} 2500$ shows throughout that dead bodies supported by struts of palm,

30 Leveque 2001. This mummy is called "the Scribe" from the old Niagara Falls Museum collection (NFM-M4), later transferred to Emory University, Atlanta, Michael C. Carlos Museum (Inv. 1999.1.11) and now in a private collection. It is contained in a yellow coffin of Twenty-first Dynasty type.

The item is called in this case a "large investing sheet" (Smith [1912] 2000, 70). 
acacia (Ar. sunt), and sesaban wood are dressed in clothing and then enfolded in wrapping shawls functioning to hold the physical remains together in a bound bundle. ${ }^{32}$ Salt has been systematically added into the resulting bundles but claims about Christian mummification such as are referred to by Budge must be toned down. ${ }^{33}$ Natural mummification (linked to the spontaneous effects of climate and soil alkalinity) is demonstrable in many cases, just as it is in earlier Egyptian mummies. If embalming is done, it is not generally being done to perfection. The old ideal of at least attempting a general drying of the body prior to burial is not adhered to as regularly as it had in pre-Christian times. Therefore, we find many examples where a salt substance (ostensibly natron but untested) has been placed into burials or packed within the wrappings to promote desiccative processes following interment. ${ }^{34}$ This contrasts with classic mummification, which always attempts to desiccate the body before deposition. That being said, Coptic "salting" of undesiccated bodies is not something unprecedented. It represents a continuation of less-stringent practices already being seen in the Roman, Ptolemaic, and indeed even in the Third Intermediate Period and earlier periods. Salting would have reduced putrefactive odors sensible to the living, and for this purpose it is sprinkled "in quantity" at a level interior to the investment shawls so that it lies on the clothing in which the corpse is dressed; sometimes it is accompanied by botanical material as well ( $\mathrm{N} 2830$ ). To a lesser extent, salt is positioned in a layer underneath the body. In burials found at other sites, embalming spices have been reported, and even significant use of juniper berries, but at Naga ed-Deir, it is only infrequently that preservative material (other than natron) is found in connection

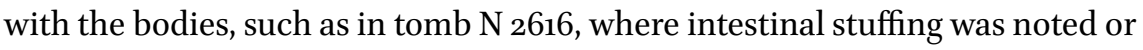
in $\mathrm{N} 2439$ where two palm sticks were placed under the body along with aromatic herbal branches. ${ }^{35}$ Other layered matter found in the burials is possibly ritual in nature, palm leaves, for example, being laced under the feet of one body ( $\mathrm{N}$ 2003). Examination of Tables 11.1 through 11.5 will give the reader an idea of the range of Coptic burial modes and their regularities.

32 Sesbania aegyptiaca, "Egyptian riverhemp", is a flowering shrub of the family Leguminosae or Fabaceae, colloquially, Egyptian pea. Sesban is the Arabic name. It is called throughout the notes "sesaban", and that usage is retained here. On the medicinal properties of this plant known as Jayanti in Hindi, see Goswami et al. (2016).

33 Budge 1894, 188.

34 Large amounts of salt $(20 \mathrm{~kg})$ used within the wrappings of a mummy discovered at el-Hibeh (NGLP-7) and systematically unwrapped in modern times is shown in Yohe, Gardner, and Heikkinen (2005, 9, fig. 10). See also Heikkinen (2012, 108).

35 For embalming spices at el-Hibeh, see Yohe, Gardner, and Heikkinen (2005). For juniper berries noted at Deir el-Bachit, see Lösch, Hower-Tillman, and Zink (2013). The intestine in the body of the young girl in tomb N 2616 had "been stuffed with preservative material." What it was exactly is not described. 
TABLE 11.1 Wrapping features Naga ed-Deir N 2000 (Tombs N 2000 to N 2033)

\begin{tabular}{|c|c|c|c|c|}
\hline $\begin{array}{l}\text { Tomb } \\
\text { number }\end{array}$ & Wrapping shawls & $\begin{array}{l}\text { Treatment of } \\
\text { the head }\end{array}$ & $\begin{array}{l}\text { Directly on the } \\
\text { body apparel worn }\end{array}$ & $\begin{array}{l}\text { Underbody } \\
\text { supports }\end{array}$ \\
\hline $\begin{array}{l}\mathrm{N} 2000 \\
\text { Adult }\end{array}$ & $\begin{array}{l}\text { Shawl outer, yellow, } \\
\text { fringed } \\
\text { Shawl inner, elaborate } \\
\text { colored wool } \\
\text { Not unwrapped in } \\
19 \circ 5\end{array}$ & $\begin{array}{l}\text { Unwrapped, } \\
\text { therefore } \\
\text { undetermined }\end{array}$ & $\begin{array}{l}\text { Unwrapped, } \\
\text { therefore } \\
\text { undetermined }\end{array}$ & $\begin{array}{l}\text { Unwrapped, } \\
\text { therefore } \\
\text { undetermined }\end{array}$ \\
\hline $\begin{array}{l}\mathrm{N} 2001 \\
\text { Adult } \mathrm{M}\end{array}$ & $\begin{array}{l}2 \text { shawls of sackcloth } \\
\text { Quantity of salt noted, } \\
\text { possibly between the } \\
\text { shawls }\end{array}$ & $\begin{array}{l}\text { Face padded } \\
\text { by an old shirt } \\
\text { Small shawl } \\
\text { around neck }\end{array}$ & $\begin{array}{l}\text { Shirt of linen, } \\
\text { neither arm in } \\
\text { sleeve }\end{array}$ & $\begin{array}{l}3 \text { palm sticks and } \\
1 \text { of sesaban } \\
\text { Salt around body }\end{array}$ \\
\hline $\begin{array}{l}\mathrm{N} 2002 \\
\text { Child F }\end{array}$ & $\begin{array}{l}\text { Shawl of coarse cloth } \\
\text { An opened-up shirt }\end{array}$ & Hat on head & $\begin{array}{l}\text { Shirt of linen } \\
\text { Layer of salt under it }\end{array}$ & 2 palm sticks \\
\hline $\begin{array}{l}\mathrm{N} 2003 \\
\text { Adult M }\end{array}$ & $\begin{array}{l}2 \text { shawls, coarse cloth } \\
\text { bound in } 2 \text {-strand } \\
\text { fiber cords }\end{array}$ & $\begin{array}{l}\text { Nothing } \\
\text { recorded }\end{array}$ & $\begin{array}{l}3 \text { shirts, linen, outer } \\
\text { and inner plain; } \\
\text { middle with blue } \\
\text { interwoven design }\end{array}$ & $\begin{array}{l}2 \text { acacia and } \\
1 \text { palm stick layer } \\
\text { of palm leaves }\end{array}$ \\
\hline $\begin{array}{l}\mathrm{N} 2004 \\
\text { Adult F }\end{array}$ & $\begin{array}{l}\text { Shawl, heliotrope } \\
\text { fringed, 2-strand fiber } \\
\text { cord } \\
2 \text { thicknesses of } \\
\text { sackcloth sewn up } \\
\text { sides }\end{array}$ & $\begin{array}{l}\text { Nothing } \\
\text { recorded }\end{array}$ & $\begin{array}{l}\text { Outer shirt, neither } \\
\text { arm in sleeve } \\
\text { 2nd shirt } \\
\text { Salt and plant seeds } \\
\text { sprinkled on body }\end{array}$ & $\begin{array}{l}3 \text { palm sticks tied } \\
\text { with fiber cords at } \\
\text { either end } \\
\text { Salt over body }\end{array}$ \\
\hline $\begin{array}{l}\mathrm{N} 2005 \\
\text { Adult M? }\end{array}$ & $\begin{array}{l}\text { Shawl, } 15^{2} \times 52 \text {, } \\
\text { fringed, bound with } \\
\text { 2-fiber cords } \\
\text { Sackcloth over cloth }\end{array}$ & $\begin{array}{l}\text { Nothing } \\
\text { recorded }\end{array}$ & $\begin{array}{l}\text { Shirt, left arm not in } \\
\text { sleeve; probably not } \\
\text { right arm either } \\
\text { Quantity of salt } \\
\text { under body }\end{array}$ & $\begin{array}{l}\text { Slat under body } \\
\text { Litter of acacia } \\
\text { stick and palm } \\
\text { stick tied together }\end{array}$ \\
\hline $\begin{array}{l}\text { N } 2006 \\
\text { Child }\end{array}$ & $\begin{array}{l}\text { Shawl, embroidered } \\
\text { Shawl, red } \\
\text { Salt noted }\end{array}$ & $\begin{array}{l}\text { Woolen } \\
\text { wrapping over } \\
\text { head } \\
\text { Circlet of palm } \\
\text { leaves }\end{array}$ & Shirt & Nothing recorded \\
\hline
\end{tabular}


TABLE 11.1 Wrapping features Naga ed-Deir N 2000 (Tombs N 2000 to N 2033) (cont.)

\begin{tabular}{|c|c|c|c|c|}
\hline $\begin{array}{l}\text { Tomb } \\
\text { number }\end{array}$ & Wrapping shawls & $\begin{array}{l}\text { Treatment of } \\
\text { the head }\end{array}$ & $\begin{array}{l}\text { Directly on the } \\
\text { body apparel worn }\end{array}$ & $\begin{array}{l}\text { Underbody } \\
\text { supports }\end{array}$ \\
\hline $\begin{array}{l}\mathrm{N} 2007 \\
\text { Adult } \mathrm{M}\end{array}$ & No cloth preserved & $\begin{array}{l}\text { Thickness of } \\
\text { sackcloth and } \\
2 \text { thicknesses } \\
\text { of cloth over } \\
\text { skull }\end{array}$ & No cloth preserved & $\begin{array}{l}\text { Palm stick under } \\
\text { each side of body }\end{array}$ \\
\hline $\begin{array}{l}\text { N } 2008 \\
\text { Child }\end{array}$ & Shawl, fringed & $\begin{array}{l}\text { Nothing } \\
\text { recorded }\end{array}$ & $\begin{array}{l}\text { Shirt, plain } \\
\text { Quantity of salt with } \\
\text { body }\end{array}$ & 3 palm sticks \\
\hline $\begin{array}{l}\text { N } 2009 \\
\text { Adult }\end{array}$ & $\begin{array}{l}\text { Sackcloth, fringed } \\
3 \text { cloth wrappings, } \\
\text { outer rough; middle, } \\
\text { medium texture; } \\
\text { inner, fine } \\
\text { Shawl, inner, then a } \\
\text { quantity of salt }\end{array}$ & $\begin{array}{l}\text { Ends of } 3 \text { cloth } \\
\text { wrappings } \\
\text { twisted } \\
\text { together over } \\
\text { face like a pad }\end{array}$ & $\begin{array}{l}2 \text { shirts, arms not in } \\
\text { sleeves }\end{array}$ & $\begin{array}{l}2 \text { thick acacia } \\
\text { sticks }\end{array}$ \\
\hline $\begin{array}{l}\mathrm{N} 2017 \\
\text { Adult M }\end{array}$ & $\begin{array}{l}\text { Poorly preserved } \\
\text { rough cloth overlying } \\
\text { wrapping of finer cloth }\end{array}$ & $\begin{array}{l}\text { Head raised by } \\
\text { small heap of } \\
\text { sand }\end{array}$ & Nothing recorded & 3 palm sticks \\
\hline $\begin{array}{l}\mathrm{N} 2033 \\
\text { Child A }\end{array}$ & $\begin{array}{l}\text { In coffin } \\
4 \text { thicknesses rough } \\
\text { cloth from } 1 \text { piece } \\
\text { wrapped around } \\
\text { (4 times) }\end{array}$ & $\begin{array}{l}\text { Pad of cloth } \\
\text { over face }\end{array}$ & Nothing recorded & $\begin{array}{l}4 \text { palm sticks } \\
\text { bound in } 3 \text { places }\end{array}$ \\
\hline $\begin{array}{l}\text { N } 2033 \\
\text { Child B }\end{array}$ & $\begin{array}{l}2 \text { coarse cloth } \\
\text { wrappings, fringed } \\
\text { Body laid on top and } \\
\text { wrapping folded over } \\
\text { Dried twigs and } \\
\text { branches within }\end{array}$ & $\begin{array}{l}\text { Meshed cloth } \\
\text { covering face }\end{array}$ & Shirt, plain & 4 palm sticks \\
\hline
\end{tabular}


TABLE 11.2 Wrapping features Naga ed-Deir N 2000 (Tombs N 2102 to N 2300)

\begin{tabular}{|c|c|c|c|c|}
\hline $\begin{array}{l}\text { Tomb } \\
\text { number }\end{array}$ & Wrapping shawls & $\begin{array}{l}\text { Treatment of } \\
\text { the head }\end{array}$ & $\begin{array}{l}\text { Directly on the } \\
\text { body apparel worn }\end{array}$ & $\begin{array}{l}\text { Underbody } \\
\text { supports }\end{array}$ \\
\hline $\begin{array}{l}\mathrm{N} 2102 \\
2 \text { Bodies }\end{array}$ & $\begin{array}{l}\text { Cloth wrappings not } \\
\text { preserved }\end{array}$ & $\begin{array}{l}\text { Nothing } \\
\text { recorded }\end{array}$ & Nothing recorded & $\begin{array}{l}\text { Each body } \\
\text { equipped } 3 \text { palm } \\
\text { sticks }\end{array}$ \\
\hline $\begin{array}{l}\mathrm{N} 2106 \\
\text { Adult } \mathrm{M}\end{array}$ & $\begin{array}{l}\text { Fine cloth wrapping } \\
\text { 2nd covering (a shirt) }\end{array}$ & $\begin{array}{l}\text { Extra quantity } \\
\text { of cloth rolled } \\
\text { up over the } \\
\text { head }\end{array}$ & $\begin{array}{l}\text { Uncertain if } 2 \text { nd } \\
\text { covering was } \\
\text { actually worn }\end{array}$ & $\begin{array}{l}2 \text { palm sticks and } \\
1 \text { acacia stick }\end{array}$ \\
\hline $\begin{array}{l}\text { N } 2107 \\
\text { Child }\end{array}$ & $\begin{array}{l}\text { Cloth wrappings not } \\
\text { preserved }\end{array}$ & $\begin{array}{l}\text { Nothing } \\
\text { recorded }\end{array}$ & Nothing recorded & $\begin{array}{l}3 \text { palm sticks } \\
\text { under the body }\end{array}$ \\
\hline $\begin{array}{l}\text { N } 2108 \mathrm{a} \\
\text { Child }\end{array}$ & Nothing recorded & $\begin{array}{l}\text { Roll of cloth by } \\
\text { head }\end{array}$ & Nothing recorded & 2 palm sticks \\
\hline $\begin{array}{l}\mathrm{N} 2108 \mathrm{~b} \\
\text { Adult } \mathrm{F}\end{array}$ & $\begin{array}{l}2 \text { or } 3 \text { thicknesses of } \\
\text { cloth }\end{array}$ & $\begin{array}{l}\text { Nothing } \\
\text { recorded }\end{array}$ & Nothing recorded & $\begin{array}{l}\text { Palm stick and } \\
\text { sesaban stick at } \\
\text { sides }\end{array}$ \\
\hline $\begin{array}{l}\text { N } 2109 \\
\text { Adult? }\end{array}$ & $\begin{array}{l}\text { Possibly recorded in } \\
\text { "Smith's Notes" }\end{array}$ & ?? & ?? & $\begin{array}{l}2 \text { pieces of sawn } \\
\text { wood }\end{array}$ \\
\hline $\begin{array}{l}\mathrm{N} 2130 \\
\text { Adult }\end{array}$ & $\begin{array}{l}\text { Fine pink cloth over } \\
\text { coarse sackcloth }\end{array}$ & $\begin{array}{l}\text { Nothing } \\
\text { recorded }\end{array}$ & $\begin{array}{l}2 \text { or } 3 \text { thicknesses of } \\
\text { finer cloth }\end{array}$ & $\begin{array}{l}\text { Litter of palm } \\
\text { sticks under } \\
\text { body but inside } \\
\text { wrappings }\end{array}$ \\
\hline $\begin{array}{l}\mathrm{N} 2133 \\
\text { Adult F }\end{array}$ & $\begin{array}{l}\text { Fine cloth over } \\
\text { sackcloth }\end{array}$ & $\begin{array}{l}\text { Nothing } \\
\text { recorded }\end{array}$ & $\begin{array}{l}2 \text { shirts } \\
\text { Quantity of salt and } \\
\text { leaves on outer shirt }\end{array}$ & $\begin{array}{l}2 \text { palm sticks } \\
\text { between shirts } \\
\text { and sackcloth }\end{array}$ \\
\hline $\begin{array}{l}\mathrm{N} 2134 \\
\text { Adult } \mathrm{M}\end{array}$ & $\begin{array}{l}\text { Shawl with patterns in } \\
\text { red thread } \\
2 \text { or } 3 \text { wrappings of } \\
\text { sackcloth }\end{array}$ & $\begin{array}{l}\text { Circlet of red } \\
\text { wool }\end{array}$ & $\begin{array}{l}\text { Fine yellow cloth } \\
\text { with sackcloth } \\
\text { overlying } \\
\text { Shirt, salt, and seeds } \\
\text { on body }\end{array}$ & $\begin{array}{l}\text { Roughly shaped } \\
\text { board }\end{array}$ \\
\hline $\begin{array}{l}\mathrm{N} 2200 \\
\text { Adult M } \\
\mathrm{N} 2201 \\
\text { Adult F }\end{array}$ & $\begin{array}{l}\text { Sackcloth poorly } \\
\text { preserved } \\
\text { Shawl of sackcloth, } \\
\text { fringed, formerly cord } \\
\text { bound }\end{array}$ & $\begin{array}{l}\text { Nothing } \\
\text { recorded } \\
\text { Net cap or } \\
\text { hood on head; } \\
\text { possible neck } \\
\text { pad }\end{array}$ & $\begin{array}{l}\text { Shirt poorly } \\
\text { preserved } \\
\text { Shirt with right } \\
\text { shoulder tassels }\end{array}$ & $\begin{array}{l}2 \text { palm sticks } \\
\text { fastened together } \\
2 \text { palm sticks } \\
\text { fastened, } \\
\text { widening to } \\
\text { shoulders }\end{array}$ \\
\hline
\end{tabular}


TABLE 11.2 Wrapping features Naga ed-Deir N 2000 (Tombs N 2102 to N 2300) (cont.)

\begin{tabular}{|c|c|c|c|c|}
\hline $\begin{array}{l}\text { Tomb } \\
\text { number }\end{array}$ & Wrapping shawls & $\begin{array}{l}\text { Treatment of } \\
\text { the head }\end{array}$ & $\begin{array}{l}\text { Directly on the } \\
\text { body apparel worn }\end{array}$ & $\begin{array}{l}\text { Underbody } \\
\text { supports }\end{array}$ \\
\hline $\begin{array}{l}\mathrm{N} 22 \mathrm{O} 2 \\
\text { Child }\end{array}$ & $\begin{array}{l}\text { White shawl formerly } \\
\text { cord bound }\end{array}$ & $\begin{array}{l}\text { Nothing } \\
\text { recorded }\end{array}$ & Shirt (plain) & \\
\hline $\begin{array}{l}\mathrm{N} 2203 \\
\text { Adult } \mathrm{F}\end{array}$ & Shawl of sackcloth & Hat or net cap & $\begin{array}{l}\text { Shawl decorated } \\
\text { with panels (flowers } \\
\text { and figures) }\end{array}$ & $\begin{array}{l}\text { Litter of } 3 \text { palm } \\
\text { sticks }\end{array}$ \\
\hline $\begin{array}{l}\mathrm{N} 2215^{\mathrm{a}} \\
\text { Adult }\end{array}$ & $\begin{array}{l}\text { Wrapped in rough } \\
\text { cloth, poorly preserved }\end{array}$ & $\begin{array}{l}\text { Pads over head } \\
\text { (and feet) }\end{array}$ & Shirts & Palm sticks \\
\hline $\begin{array}{l}\mathrm{N} 2215^{\mathrm{b}} \\
\text { Child F }\end{array}$ & $\begin{array}{l}\text { Fine cloth shawl } \\
\text { Shawl of sackcloth }\end{array}$ & $\begin{array}{l}\text { Traces of shirt } \\
\text { are implied }\end{array}$ & Shirts & Palm sticks \\
\hline $\begin{array}{l}\mathrm{N} 2218 \\
\text { Adult F }\end{array}$ & Cloth poorly preserved & $\begin{array}{l}\text { Rolled-up, } \\
\text { fringed } \\
\text { sackcloth } \\
\text { Shawl over } \\
\text { head }\end{array}$ & Nothing recorded & Nothing recorded \\
\hline $\begin{array}{l}\mathrm{N} 2219 \\
\text { Adult }\end{array}$ & Poorly preserved & $\begin{array}{l}\text { Nothing } \\
\text { recorded }\end{array}$ & Nothing recorded & $\begin{array}{l}1 \text { palm stick and } \\
1 \text { spade-handle of } \\
\text { wood }\end{array}$ \\
\hline $\begin{array}{l}\text { N } 2241 \\
\text { Adult F }\end{array}$ & Poorly preserved & $\begin{array}{l}\text { Nothing } \\
\text { recorded }\end{array}$ & Nothing recorded & Nothing recorded \\
\hline $\begin{array}{l}\text { N } 2243 \\
\text { Child }\end{array}$ & Poorly preserved & $\begin{array}{l}\text { Nothing } \\
\text { recorded }\end{array}$ & Nothing recorded & Nothing recorded \\
\hline $\begin{array}{l}\mathrm{N} 2243 \\
\text { Adult M }\end{array}$ & Poorly preserved & $\begin{array}{l}\text { Nothing } \\
\text { recorded }\end{array}$ & Nothing recorded & Nothing recorded \\
\hline $\begin{array}{l}\text { N } 2273 \\
\text { Child }\end{array}$ & Poorly preserved & $\begin{array}{l}\text { Nothing } \\
\text { recorded }\end{array}$ & Nothing recorded & Nothing recorded \\
\hline $\begin{array}{l}\mathrm{N} 2300 \\
\text { Adult }\end{array}$ & Poorly preserved & $\begin{array}{l}\text { Palm fiber over } \\
\text { head }\end{array}$ & Nothing recorded & $\begin{array}{l}\text { Litter of } 2 \text { sticks } \\
\text { of acacia }\end{array}$ \\
\hline
\end{tabular}


TABLE 11.3 Wrapping features Naga ed-Deir N 2000/N 2500 (Tombs N 2410 to N 2509)

\begin{tabular}{|c|c|c|c|c|}
\hline $\begin{array}{l}\text { Tomb } \\
\text { number }\end{array}$ & Wrapping shawls & $\begin{array}{l}\text { Treatment of } \\
\text { the head }\end{array}$ & $\begin{array}{l}\text { Directly on the } \\
\text { body apparel worn }\end{array}$ & $\begin{array}{l}\text { Underbody } \\
\text { supports }\end{array}$ \\
\hline $\begin{array}{l}\mathrm{N} 2410 \\
\text { Adult } \mathrm{M}\end{array}$ & $\begin{array}{l}\text { Shawl of sackcloth } \\
\text { Shawl }\end{array}$ & $\begin{array}{l}\text { Nothing } \\
\text { recorded }\end{array}$ & Shirt, yellow & Nothing recorded \\
\hline $\begin{array}{l}\text { N } 2411 \\
\text { Adult }\end{array}$ & $\begin{array}{l}\text { Several wrappings, } \\
\text { woven tapestry } \\
\text { (remains only) }\end{array}$ & $\begin{array}{l}\text { Nothing } \\
\text { recorded }\end{array}$ & Nothing recorded & 2 palm sticks \\
\hline $\begin{array}{l}\mathrm{N} 2412 \\
\text { Adult M }\end{array}$ & $\begin{array}{l}\text { Shawl of sackcloth } \\
\text { Shawl of fine cloth } \\
\text { with woven tapestry } \\
\text { designs, poorly } \\
\text { preserved }\end{array}$ & $\begin{array}{l}\text { Nothing } \\
\text { recorded }\end{array}$ & Nothing recorded & Nothing recorded \\
\hline $\begin{array}{l}\mathrm{N} 2413 \\
\text { Adult M }\end{array}$ & $\begin{array}{l}\text { Shawl of yellow cloth } \\
\text { Shawl of sackcloth, } \\
\text { fringed with open } \\
\text { work ends } \\
\text { Shawl of coarse cloth }\end{array}$ & $\begin{array}{l}\text { Pad of cloth } \\
\text { over head } \\
\text { made from an } \\
\text { old shirt }\end{array}$ & $\begin{array}{l}\text { Shirt, arms not in } \\
\text { sleeves } \\
\text { Plant seeds on body }\end{array}$ & $\begin{array}{l}\text { Sticks of sesaban/ } \\
\text { palm on left/right } \\
\text { sides of body }\end{array}$ \\
\hline $\begin{array}{l}\mathrm{N} 2414 \\
\text { Adult }\end{array}$ & $\begin{array}{l}\text { Shawl of sackcloth } \\
\text { Shawl of finer cloth }\end{array}$ & $\begin{array}{l}\text { Pad of cloth } \\
\text { over head } \\
\text { made from old } \\
\text { shirt }\end{array}$ & Nothing recorded & Nothing recorded \\
\hline $\begin{array}{l}\mathrm{N} 2414 \\
\text { Child }\end{array}$ & Poorly preserved & $\begin{array}{l}\text { Nothing } \\
\text { recorded }\end{array}$ & Nothing recorded & Palm sticks \\
\hline $\begin{array}{l}\text { N } 2414 \\
\text { Child }\end{array}$ & Poorly preserved & $\begin{array}{l}\text { Nothing } \\
\text { recorded }\end{array}$ & Nothing recorded & Palm sticks \\
\hline $\mathrm{N} 2415$ & Shawl of sackcloth & Sheep-hide & 2 shirts & 5 palm sticks \\
\hline Adult M & Shawl of finer cloth & $\begin{array}{l}\text { with wool and } \\
\text { bundles of } \\
\text { straw corded- } \\
\text { up padding the } \\
\text { head }\end{array}$ & Salt layer overlying & bound together \\
\hline
\end{tabular}


TABLE 11.3 Wrapping features Naga ed-Deir N 2000/N 2500 (Tombs N 2410 to N 2509) (cont.)

\begin{tabular}{|c|c|c|c|c|}
\hline $\begin{array}{l}\text { Tomb } \\
\text { number }\end{array}$ & Wrapping shawls & $\begin{array}{l}\text { Treatment of } \\
\text { the head }\end{array}$ & $\begin{array}{l}\text { Directly on the } \\
\text { body apparel worn }\end{array}$ & $\begin{array}{l}\text { Underbody } \\
\text { supports }\end{array}$ \\
\hline $\begin{array}{l}\mathrm{N} 2416 \\
\text { Adult }\end{array}$ & $\begin{array}{l}\text { Shawl of rough } \\
\text { sackcloth }\end{array}$ & $\begin{array}{l}\text { Elaborate pads: } \\
\text { a roll of fine } \\
\text { cloth, loose } \\
\text { straw with } \\
5 \text { separately } \\
\text { corded straw } \\
\text { bundles, then } \\
\text { secured by cloth }\end{array}$ & $\begin{array}{l}2 \text { plain shirts of } \\
\text { coarse cloth, right } \\
\text { arm in outer sleeve } \\
\text { but not in inner; left } \\
\text { arm in inner sleeve } \\
\text { but not in outer }\end{array}$ & $\begin{array}{l}\text { Body tied onto } \\
\text { flat board }\end{array}$ \\
\hline $\begin{array}{l}\mathrm{N} 2417 \\
\text { Adult M }\end{array}$ & Poorly preserved & $\begin{array}{l}\text { Nothing } \\
\text { recorded }\end{array}$ & Nothing recorded & Nothing recorded \\
\hline $\begin{array}{l}\text { N } 2418 \\
\text { Child }\end{array}$ & Poorly preserved & $\begin{array}{l}\text { Nothing } \\
\text { recorded }\end{array}$ & Nothing recorded & Nothing recorded \\
\hline $\begin{array}{l}\mathrm{N} 2419 \\
\text { Adult M }\end{array}$ & $\begin{array}{l}\text { Red cloth } \\
\text { Shawl of sackcloth }\end{array}$ & $\begin{array}{l}\text { Pad consisting } \\
\text { of a shirt on } \\
\text { head }\end{array}$ & Shirt & $\begin{array}{l}3 \text { or } 4 \text { sticks of } \\
\text { sesaban }\end{array}$ \\
\hline $\begin{array}{l}\mathrm{N} 2438 \\
\text { Adult }\end{array}$ & Shawl of sackcloth & $\begin{array}{l}\text { Layer of reeds } \\
\text { tied to face } \\
2 \text { cloth pads } \\
\text { consisting of } \\
\text { old shirt }\end{array}$ & $\begin{array}{l}\text { Fragmentary shawl } \\
\text { of coarse cloth } \\
\text { over a shirt, poorly } \\
\text { preserved }\end{array}$ & \\
\hline $\begin{array}{l}\text { N } 2439 \\
\text { Child }\end{array}$ & $\begin{array}{l}\text { Shawl of sackcloth } \\
\text { bound with cords } \\
\text { crossing in "all } \\
\text { directions" }\end{array}$ & $\begin{array}{l}\text { Thick pad on } \\
\text { head (and on } \\
\text { feet) }\end{array}$ & $\begin{array}{l}\text { Shirt (plain) } \\
\text { Branches of } \\
\text { aromatic herb on } \\
\text { body }\end{array}$ & 2 palm sticks \\
\hline $\begin{array}{l}\text { N } 2441 \\
\text { Child }\end{array}$ & No cloth preserved & $\begin{array}{l}\text { No cloth } \\
\text { recorded }\end{array}$ & No cloth recorded & Nothing recorded \\
\hline $\begin{array}{l}\mathrm{N} 25 \circ 3 \\
\text { Adult } \mathrm{M}\end{array}$ & $\begin{array}{l}\text { Outer shawl of } \\
\text { sackcloth } \\
\text { Inner shawl of coarse } \\
\text { cloth }\end{array}$ & $\begin{array}{l}\text { Small shawl } \\
\text { folded as pad } \\
\text { on face }\end{array}$ & Shirt (plain) & $\begin{array}{l}\text { 1 stick acacia, } \\
1 \text { stick tamarisk }\end{array}$ \\
\hline $\begin{array}{l}\mathrm{N} 2504 \\
\text { Child a. }\end{array}$ & $\begin{array}{l}\text { Poorly preserved } \\
\text { Outer wrapping of } \\
\text { coarse cloth }\end{array}$ & $\begin{array}{l}\text { Nothing } \\
\text { recorded }\end{array}$ & $\begin{array}{l}2 \text { shirts, } \\
\text { tapestry-woven }\end{array}$ & Nothing recorded \\
\hline
\end{tabular}


TABLE 11.3 Wrapping features Naga ed-Deir N 2000/N 2500 (Tombs N 2410 to N 2509) (cont.)

\begin{tabular}{|c|c|c|c|c|}
\hline $\begin{array}{l}\text { Tomb } \\
\text { number }\end{array}$ & Wrapping shawls & $\begin{array}{l}\text { Treatment of } \\
\text { the head }\end{array}$ & $\begin{array}{l}\text { Directly on the } \\
\text { body apparel worn }\end{array}$ & $\begin{array}{l}\text { Underbody } \\
\text { supports }\end{array}$ \\
\hline $\begin{array}{l}\mathrm{N}_{25} \mathrm{O}_{4} \\
\text { Child b. }\end{array}$ & $\begin{array}{l}\text { Outer shawl, green } \\
\text { cloth bound by cords } \\
\text { Inner shawl }\end{array}$ & $\begin{array}{l}\text { Net hood or } \\
\text { hat on head }\end{array}$ & $\begin{array}{l}2 \text { shirts, tapestry } \\
\text { woven }\end{array}$ & 2 palm sticks \\
\hline $\begin{array}{l}\mathrm{N} 2505 \\
\text { Adult F }\end{array}$ & Poorly preserved & $\begin{array}{l}\text { Nothing } \\
\text { recorded }\end{array}$ & No cloth recorded & Nothing recorded \\
\hline $\begin{array}{l}\mathrm{N} 25^{\circ 6} \\
\text { Child F }\end{array}$ & No cloth recorded & $\begin{array}{l}\text { Nothing } \\
\text { recorded }\end{array}$ & No cloth recorded & Nothing recorded \\
\hline $\begin{array}{l}\mathrm{N} 2508 \\
\text { Adult } \mathrm{M}\end{array}$ & $\begin{array}{l}\text { Poorly preserved } \\
\text { Outer shawl of } \\
\text { sackcloth } \\
\text { Inner shawl of finer } \\
\text { cloth }\end{array}$ & $\begin{array}{l}\text { Nothing } \\
\text { recorded }\end{array}$ & No cloth recorded & $\begin{array}{l}2 \text { palm sticks or } \\
\text { more }\end{array}$ \\
\hline $\begin{array}{l}\mathrm{N} 2509 \\
\text { Adult } \mathrm{M}\end{array}$ & $\begin{array}{l}\text { Poorly preserved } \\
\text { Little cloth remaining }\end{array}$ & $\begin{array}{l}\text { Nothing } \\
\text { recorded }\end{array}$ & No cloth recorded & $\begin{array}{l}\text { Stick of sesaban } \\
\text { on either side of } \\
\text { body }\end{array}$ \\
\hline
\end{tabular}

TABLE 11.4 Wrapping features Naga ed-Deir N 2500 (Tombs N 2610 to N 2700)

\begin{tabular}{|c|c|c|c|c|}
\hline $\begin{array}{l}\text { Tomb } \\
\text { number }\end{array}$ & Wrapping shawls & $\begin{array}{l}\text { Treatment of } \\
\text { the head }\end{array}$ & $\begin{array}{l}\text { Directly on the } \\
\text { body apparel worn }\end{array}$ & $\begin{array}{l}\text { Underbody } \\
\text { supports }\end{array}$ \\
\hline $\begin{array}{l}\mathrm{N} 2610 \\
\text { Adult F }\end{array}$ & $\begin{array}{l}\text { Body well preserved; } \\
\text { salty substance noted } \\
\text { Outer shawl of } \\
\text { sackcloth } \\
\text { Inner shawl of fine } \\
\text { cloth, fringed }\end{array}$ & $\begin{array}{l}\text { Nothing } \\
\text { recorded }\end{array}$ & Shirt (plain) & \\
\hline $\begin{array}{l}\text { N } 2611 \\
\text { Child }\end{array}$ & $\begin{array}{l}\text { Outer shawl of } \\
\text { sackcloth-bound with } \\
\text { 2-strand fiber cords } \\
\text { Inner shawl of fine } \\
\text { cloth }\end{array}$ & $\begin{array}{l}\text { Pad of extra } \\
\text { cloth over } \\
\text { head (a mesh } \\
\text { shawl) }\end{array}$ & Shirt of fine cloth & $\begin{array}{l}3 \text { palm sticks next } \\
\text { to body }\end{array}$ \\
\hline
\end{tabular}


TABLE 11.4 Wrapping features Naga ed-Deir N 2500 (Tombs N 2610 to N 2700) (cont.)

\begin{tabular}{|c|c|c|c|c|}
\hline $\begin{array}{l}\text { Tomb } \\
\text { number }\end{array}$ & Wrapping shawls & $\begin{array}{l}\text { Treatment of } \\
\text { the head }\end{array}$ & $\begin{array}{l}\text { Directly on the } \\
\text { body apparel worn }\end{array}$ & $\begin{array}{l}\text { Underbody } \\
\text { supports }\end{array}$ \\
\hline $\begin{array}{l}\mathrm{N}_{2} 612 \\
\text { Adult a. }\end{array}$ & Wrapping shawls & $\begin{array}{l}\text { Extra padding } \\
\text { over face; cloth } \\
\text { square and } \\
\text { old shirt rolled } \\
\text { inside coarse } \\
\text { cloth }\end{array}$ & $\begin{array}{l}\text { Shirt, arms not in } \\
\text { sleeves }\end{array}$ & 2 palm sticks \\
\hline $\begin{array}{l}\mathrm{N} 2612 \\
\text { Adult b. }\end{array}$ & $\begin{array}{l}\text { Shawl of rough cloth } \\
\text { Shirt (old) of finer } \\
\text { material }\end{array}$ & $\begin{array}{l}\text { Nothing } \\
\text { recorded }\end{array}$ & 2 shirts & $\begin{array}{l}2 \text { sticks of } \\
\text { sesaban }\end{array}$ \\
\hline $\begin{array}{l}\mathrm{N} 2613 \\
\text { Adult F }\end{array}$ & $\begin{array}{l}\text { Outer shawl with } \\
\text { designs in colored wool } \\
\text { Inner shawl of fine } \\
\text { cloth with tapestry- } \\
\text { woven designs } \\
\text { Inner shawl (coarse } \\
\text { cloth implied in notes) }\end{array}$ & $\begin{array}{l}\text { Nothing } \\
\text { recorded }\end{array}$ & Shirt & Nothing recorded \\
\hline $\begin{array}{l}\mathrm{N} 2615 \\
\text { Adult F }\end{array}$ & $\begin{array}{l}2 \text { or } 3 \text { wrapping shawls } \\
\text { of sackcloth } \\
\text { Traces of } 2 \text {-strand } \\
\text { fiber cords }\end{array}$ & $\begin{array}{l}\text { Nothing } \\
\text { recorded }\end{array}$ & $\begin{array}{l}\text { Shirt (plain) } \\
\text { Salt in quantity on } \\
\text { body with dried fruit } \\
\text { and seeds }\end{array}$ & $\begin{array}{l}4 \text { palm sticks } \\
\text { Below body, dried } \\
\text { palm leaves, } \\
2 \text { tied together }\end{array}$ \\
\hline $\begin{array}{l}\mathrm{N} 2616 \\
\text { Child F }\end{array}$ & $\begin{array}{l}\text { Shawl of ordinary } \\
\text { cloth, fringed } \\
\text { Shawl of sackcloth }\end{array}$ & $\begin{array}{l}\text { Nothing } \\
\text { recorded }\end{array}$ & Shirt & Nothing recorded \\
\hline $\begin{array}{l}\mathrm{N} 2619 \\
\text { Adult }\end{array}$ & $\begin{array}{l}\text { Poorly preserved } \\
\text { Outer wrapping cloth } \\
\text { Inner wrapping } \\
\text { sackcloth }\end{array}$ & $\begin{array}{l}\text { Nothing } \\
\text { recorded }\end{array}$ & No cloth recorded & 2 palm sticks \\
\hline $\begin{array}{l}\mathrm{N} 2632 \\
\text { Adult } \mathrm{M}\end{array}$ & $\begin{array}{l}\text { Outer shawl of finer } \\
\text { cloth, tassled } \\
\text { Inner shawl of } \\
\text { sackcloth }\end{array}$ & $\begin{array}{l}\text { Nothing } \\
\text { recorded }\end{array}$ & $\begin{array}{l}\text { Shirt poorly } \\
\text { preserved; salt on } \\
\text { the body }\end{array}$ & $\begin{array}{l}4 \text { palm sticks, tied } \\
\text { together } 2 \text { per } \\
\text { side in sackcloth }\end{array}$ \\
\hline $\begin{array}{l}\mathrm{N} 2633 \\
\text { Adult } \mathrm{M}\end{array}$ & $\begin{array}{l}\text { Outer shawl of } \\
\text { sackcloth } \\
\text { Inner shawl of fine } \\
\text { cloth }\end{array}$ & $\begin{array}{l}\text { Nothing } \\
\text { recorded }\end{array}$ & Shirt (plain) & $\begin{array}{l}2 \text { palm sticks in } \\
\text { sackcloth }\end{array}$ \\
\hline
\end{tabular}


TABLE 11.4 Wrapping features Naga ed-Deir N 2500 (Tombs N 2610 to N 2700) (cont.)

\begin{tabular}{|c|c|c|c|c|}
\hline $\begin{array}{l}\text { Tomb } \\
\text { number }\end{array}$ & Wrapping shawls & $\begin{array}{l}\text { Treatment of } \\
\text { the head }\end{array}$ & $\begin{array}{l}\text { Directly on the } \\
\text { body apparel worn }\end{array}$ & $\begin{array}{l}\text { Underbody } \\
\text { supports }\end{array}$ \\
\hline $\begin{array}{l}\mathrm{N} 2634 \\
\text { Adult F }\end{array}$ & $\begin{array}{l}2 \text { wrapping shawls of } \\
\text { coarse cloth }\end{array}$ & $\begin{array}{l}\text { Nothing } \\
\text { recorded }\end{array}$ & $\begin{array}{l}\text { Shirt (plain) } \\
\text { Salt on body }\end{array}$ & $\begin{array}{l}2 \text { palm sticks } \\
\text { bound together } \\
\text { Salt under body }\end{array}$ \\
\hline $\begin{array}{l}\mathrm{N} 2635 \\
\text { Adult } \mathrm{M}\end{array}$ & Shawl of sackcloth & $\begin{array}{l}\text { Nothing } \\
\text { recorded }\end{array}$ & $\begin{array}{l}\text { Shirt with corded } \\
\text { edges }\end{array}$ & Nothing recorded \\
\hline $\begin{array}{l}\mathrm{N} 2636 \\
\text { Adult F }\end{array}$ & $\begin{array}{l}\text { Outer shawl of coarse } \\
\text { cloth, fringed with } \\
\text { tapestry-woven wool, } \\
\text { bound in cordage } \\
\text { Inner shawl of yellow } \\
\text { cloth laid on body }\end{array}$ & $\begin{array}{l}\text { Net veil or } \\
\text { head shawl of } \\
\text { yellow linen } \\
\text { and wool, } \\
\text { covered by } \\
\text { shawl rolled } \\
\text { into a pad }\end{array}$ & $\begin{array}{l}\text { Shirt } \\
\text { Plaid shawl next to } \\
\text { skin } \\
\text { Quantity of salt on } \\
\text { body }\end{array}$ & $\begin{array}{l}2 \text { palm sticks and } \\
1 \text { sesaban stick }\end{array}$ \\
\hline $\begin{array}{l}\mathrm{N} 2637 \\
\text { Adult M }\end{array}$ & $\begin{array}{l}\text { Outer shawl of } \\
\text { sackcloth } \\
\text { Middle shawl of } \\
\text { sackcloth } \\
\text { Inner shawl of coarse } \\
\text { cloth }\end{array}$ & $\begin{array}{l}\text { Pad made of } \\
\text { old shirt rolled } \\
\text { into a ball, } \\
\text { tapestry-woven } \\
\text { 2-strand cord } \\
\text { tied on head }\end{array}$ & $\begin{array}{l}\text { Shirt } \\
\text { Quantity of salt and } \\
\text { seeds }\end{array}$ & $\begin{array}{l}\text { Litter of } 1 \text { palm } \\
\text { stick and } 1 \text { of } \\
\text { shaum }\end{array}$ \\
\hline $\mathrm{N} 2638$ & $\begin{array}{l}\text { Shawl of sackcloth } \\
\text { Coarse linen }\end{array}$ & $\begin{array}{l}\text { Nothing } \\
\text { recorded }\end{array}$ & $\begin{array}{l}\text { Single shirt } \\
\text { undecorated }\end{array}$ & $\begin{array}{l}3 \text { sticks wrapped } \\
\text { in coarse linen }(2)\end{array}$ \\
\hline $\begin{array}{l}\mathrm{N} 2639 \\
\text { Adult M }\end{array}$ & $\begin{array}{l}\text { Wrapping shawl of } \\
\text { fine linen, fringed }\end{array}$ & $\begin{array}{l}\text { Nothing } \\
\text { recorded }\end{array}$ & $\begin{array}{l}2 \text { shirts, corded } \\
\text { edges, tapestry- } \\
\text { woven decoration }\end{array}$ & Nothing recorded \\
\hline $\begin{array}{l}\text { N } 2700 \\
\text { Adult F }\end{array}$ & $\begin{array}{l}\text { Outer shawl, fine } \\
\text { wide-meshed red cloth } \\
\text { Shawl of white cloth } \\
\text { Shawl of white cloth } \\
\text { Shawl of white cloth } \\
\text { Shawl of yellow cloth } \\
\text { Inner shawl, fine wide- } \\
\text { meshed black cloth }\end{array}$ & $\begin{array}{l}\text { Nothing } \\
\text { recorded }\end{array}$ & $\begin{array}{l}\text { Shirt with tapestry- } \\
\text { woven designs }\end{array}$ & 4 palm sticks \\
\hline
\end{tabular}


TABLE 11.5 Wrapping features Naga ed-Deir N 250o (Tombs N 2806 to N 2839)

\begin{tabular}{|c|c|c|c|c|}
\hline $\begin{array}{l}\text { Tomb } \\
\text { number }\end{array}$ & Wrapping shawls & $\begin{array}{l}\text { Treatment of } \\
\text { the head }\end{array}$ & $\begin{array}{l}\text { Directly on the } \\
\text { body apparel worn }\end{array}$ & $\begin{array}{l}\text { Underbody } \\
\text { supports }\end{array}$ \\
\hline $\begin{array}{l}\mathrm{N} 2806 \\
\text { Adult M }\end{array}$ & $\begin{array}{l}\text { Outer covering of fine } \\
\text { cloth, yellow } \\
\text { Middle shawl of } \\
\text { sackcloth } \\
\text { Inner shawl of coarse } \\
\text { cloth }\end{array}$ & $\begin{array}{l}\text { Extra pad over } \\
\text { face } \\
\text { Salt }\end{array}$ & Shirt & 2 stout poles \\
\hline $\begin{array}{l}\mathrm{N} 2810 \\
\text { Adult }\end{array}$ & $\begin{array}{l}\text { Poorly preserved } \\
\text { Sackcloth traces } \\
\text { Finer cloth traces }\end{array}$ & Head missing & No cloth recorded & 2 palm sticks \\
\hline $\begin{array}{l}\mathrm{N} 2811 \\
\text { Adult F }\end{array}$ & Sackcloth & $\begin{array}{l}\text { Extra } \\
\text { wrappings over } \\
\text { head }\end{array}$ & $\begin{array}{l}\text { Shirt, poorly } \\
\text { preserved but had } \\
\text { been elaborate }\end{array}$ & $\begin{array}{l}2 \text { palm sticks } \\
\text { Salt with body }\end{array}$ \\
\hline $\begin{array}{l}\mathrm{N} 2812 \\
\text { Child }\end{array}$ & $\begin{array}{l}\text { Outer wrapping of } \\
\text { yellow cloth } \\
\text { Rough cloth (not } \\
\text { sackcloth) bound with } \\
\text { cords }\end{array}$ & $\begin{array}{l}2 \text { or } 3 \\
\text { thicknesses of } \\
\text { soft wool fiber }\end{array}$ & $\begin{array}{l}2 \text { shirts (upper shirt } \\
\text { inside out) }\end{array}$ & Twigs and leaves \\
\hline $\begin{array}{l}\mathrm{N} 2813 \\
\text { Infant }\end{array}$ & $\begin{array}{l}\text { Poorly preserved } \\
\text { Traces of cloth }\end{array}$ & $\begin{array}{l}\text { Nothing } \\
\text { recorded }\end{array}$ & No cloth recorded & Nothing recorded \\
\hline $\begin{array}{l}\mathrm{N} 2814 \\
\text { Adult }\end{array}$ & Poorly preserved & $\begin{array}{l}\text { Large pad over } \\
\text { head, some } \\
\text { embroidery }\end{array}$ & No cloth recorded & 2 palm sticks \\
\hline $\begin{array}{l}\mathrm{N} 2815 \\
\text { Adult }\end{array}$ & $\begin{array}{l}\text { Outer wrapping of } \\
\text { finer cloth } \\
\text { Inner wrapping of } \\
\text { sackcloth }\end{array}$ & $\begin{array}{l}\text { Large pad over } \\
\text { head }\end{array}$ & No cloth recorded & 2 palm sticks \\
\hline $\begin{array}{l}\mathrm{N} 2816 \\
\text { Adult M }\end{array}$ & Poorly preserved & $\begin{array}{l}\text { Nothing } \\
\text { recorded }\end{array}$ & No cloth recorded & $\begin{array}{l}6 \text { palm sticks: } 2 \\
\text { on each side, } 2 \text { in } \\
\text { the middle }\end{array}$ \\
\hline $\begin{array}{l}\mathrm{N} 2817 \\
\text { Adult F }\end{array}$ & $\begin{array}{l}\text { Poorly preserved } \\
\text { Wrappings of } \\
\text { sackcloth and finer } \\
\text { cloth (order not } \\
\text { described) }\end{array}$ & $\begin{array}{l}\text { Nothing } \\
\text { recorded }\end{array}$ & No cloth recorded & 2 palm sticks \\
\hline
\end{tabular}


TABLE 11.5 Wrapping features Naga ed-Deir N 2500 (Tombs N 2806 to N 2839) (cont.)

\begin{tabular}{|c|c|c|c|c|}
\hline $\begin{array}{l}\text { Tomb } \\
\text { number }\end{array}$ & Wrapping shawls & $\begin{array}{l}\text { Treatment of } \\
\text { the head }\end{array}$ & $\begin{array}{l}\text { Directly on the } \\
\text { body apparel worn }\end{array}$ & $\begin{array}{l}\text { Underbody } \\
\text { supports }\end{array}$ \\
\hline $\begin{array}{l}\mathrm{N}_{2} 818 \\
\text { Adult } \mathrm{M}\end{array}$ & Poorly preserved & $\begin{array}{l}\text { Large pad } \\
\text { consisting of } \\
\text { finer cloth } \\
\text { inside of } \\
\text { sackcloth }\end{array}$ & Nothing recorded & $\begin{array}{l}2 \text { palm sticks on } \\
\text { right } \\
1 \text { palm stick on } \\
\text { left }\end{array}$ \\
\hline $\begin{array}{l}\text { N } 2819 \\
\text { Adult }\end{array}$ & Poorly preserved & Head missing & No cloth described & $\begin{array}{l}1 \text { palm stick } \\
1 \text { sesaban stick }\end{array}$ \\
\hline $\begin{array}{l}\mathrm{N} 2830(1) \\
\text { Adult }\end{array}$ & Rough sackcloth & $\begin{array}{l}\text { Nothing } \\
\text { reported }\end{array}$ & Nothing reported & Nothing reported \\
\hline $\begin{array}{l}\mathrm{N} 2830(2) \\
\text { Adult } \mathrm{M}\end{array}$ & $\begin{array}{l}\text { Shawl of yellow cloth } \\
\text { tied with fiber cords } \\
\text { Shawl of sackcloth } \\
\text { sewn up with cord } \\
\text { Inner shawl of coarse } \\
\text { cloth with wool border }\end{array}$ & $\begin{array}{l}\text { Quantity of } \\
\text { palm fiber over } \\
\text { the head } \\
\text { Pad of cloth } \\
\text { on head } \\
\text { (consisting of } \\
\text { old shirt rolled } \\
\text { into a ball) } \\
\text { positioned } \\
\text { over inner } \\
\text { shawl }\end{array}$ & $\begin{array}{l}\text { Shirt covered with } \\
\text { small amount of salt } \\
\text { and dried plants on } \\
\text { breast } \\
2 \text { more shirts, body's } \\
\text { arms in-the-sleeves } \\
\text { of outer shirt; arms } \\
\text { not-in-the-sleeves of } \\
\text { inner shirt } \\
\text { Lock of female } \\
\text { hair (curled) in the } \\
\text { wrappings }\end{array}$ & $\begin{array}{l}4 \text { palm sticks and } \\
1 \text { acacia stick } \\
\text { fastened together } \\
\text { Dried palm leaves }\end{array}$ \\
\hline $\begin{array}{l}\mathrm{N}_{28} 81 \\
\text { Adult F }\end{array}$ & $\begin{array}{l}\text { Poorly preserved cloth } \\
\text { wrappings }\end{array}$ & $\begin{array}{l}\text { Nothing } \\
\text { reported }\end{array}$ & Nothing reported & $\begin{array}{l}\text { Palm sticks under } \\
\text { body and a few } \\
\text { palm leaves }\end{array}$ \\
\hline $\begin{array}{l}\mathrm{N} 2833 \\
\text { Adult M }\end{array}$ & $\begin{array}{l}\text { Outer wrapping of } \\
\text { sackcloth bound with } \\
\text { strips of coarse white } \\
\text { cloth, with red and } \\
\text { black ornamentation, } \\
\text { and fiber cords } \\
\text { Middle wrapping of } \\
\text { sackcloth } \\
\text { Inner wrapping of } \\
\text { sackcloth }\end{array}$ & $\begin{array}{l}\text { Ball of fine, } \\
\text { soft cloth } \\
\text { with pattern } \\
\text { in purple, } \\
\text { placed by right } \\
\text { side of face, } \\
\text { over middle } \\
\text { wrapping }\end{array}$ & $\begin{array}{l}2 \text { shirts of fine linen } \\
\text { positioned under } \\
\text { inner wrapping }\end{array}$ & $\begin{array}{l}1 \text { stick for } \\
\text { carrying inside } \\
\text { sackcloth } \\
\text { wrappings }\end{array}$ \\
\hline
\end{tabular}


TABLE 11.5 Wrapping features Naga ed-Deir N 2500 (Tombs N 2806 to N 2839) (cont.)

\begin{tabular}{|c|c|c|c|c|}
\hline $\begin{array}{l}\text { Tomb } \\
\text { number }\end{array}$ & Wrapping shawls & $\begin{array}{l}\text { Treatment of } \\
\text { the head }\end{array}$ & $\begin{array}{l}\text { Directly on the } \\
\text { body apparel worn }\end{array}$ & $\begin{array}{l}\text { Underbody } \\
\text { supports }\end{array}$ \\
\hline $\begin{array}{l}\mathrm{N} 2836 \\
\text { Adult }\end{array}$ & $\begin{array}{l}\text { Wrapping of yellow } \\
\text { cloth with green motif } \\
\text { Thickness of sackcloth } \\
\text { Thickness of sackcloth } \\
\text { Wrapping of fine cloth } \\
\text { (Sequence may be } \\
\text { reversed) }\end{array}$ & $\begin{array}{l}2 \text { large } \\
\text { bunches of } \\
\text { grass, tied } \\
\text { round over } \\
\text { head } \\
\text { Mass of cloth } \\
\text { on head }\end{array}$ & $\begin{array}{l}\text { Shirt } \\
\text { Quantity of salt on } \\
\text { body }\end{array}$ & $\begin{array}{l}3 \text { palm sticks } \\
\text { and } 1 \text { atl. (?) } \\
\text { tied together in } \\
\text { sackcloth }\end{array}$ \\
\hline $\begin{array}{l}\mathrm{N} 2839 \\
\text { Adult } \mathrm{M}\end{array}$ & $\begin{array}{l}\text { Poorly preserved } \\
\text { Remains of several } \\
\text { linen wrappings with } \\
\text { decoration in colored } \\
\text { wools }\end{array}$ & $\begin{array}{l}\text { Nothing } \\
\text { recorded }\end{array}$ & $\begin{array}{l}\text { Shirt with breast } \\
\text { ornamentation }\end{array}$ & $\begin{array}{l}3 \text { palm sticks tied } \\
\text { together, above } 2 \\
\text { wrappings } \\
\text { Twigs and dried } \\
\text { leaves between }\end{array}$ \\
\hline
\end{tabular}

The emphasis on putting the body into daily dress is a very different approach to burial when contrasted to earlier periods during which bodies are undressed when invested in bandaging. Coptic bodies at Naga ed-Deir N 2000/N 2500 tend to be buried at shallow levels along an east-west orientation. ${ }^{36} \mathrm{~A}$ body is typically placed on its back with its head to the west as in other Coptic cemeteries. ${ }^{37}$ The arms frequently lie at the sides of the bodies ( $\mathrm{N}$ 2001, $\mathrm{N} 2002)$.

A class of textile, the so-called "wrapping shawl", is referred to throughout the notes. They often have fringed edges. Many are made of a coarse-weave fabric or an even cruder weave described in the notes as "sackcloth". ${ }^{38}$ Because of their context of discovery, the "wrapping shawls" might be interpreted as

36 Shallow burial is by no means a Christian innovation; it is seen widely in the Late Period at sites such as Saqqara and Abusir. However, the consistent East-West orientation of the

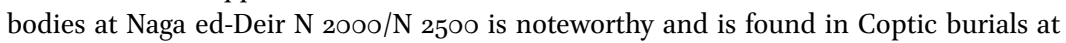
other sites, for example, at el-Hibeh.

37 Heikkinen $(2012,114)$ notes head-west burials at Fag el-Gamous. At this site, the loci "regularly have at least two bodies interred together, and in some cases as many as nine...."

38 A fabric with thick ridges of tightly coiled fabric strands. The material of the base thread appears fibrous but is not identified. 
specifically created for funerary purposes. However, at least some of them were articles of clothing worn in life, similar to the hulaleeyah described by Edward William Lane interestingly enough, specifically in connection with habits of dress found "above Akhmim". ${ }^{9}$ The shawls are used somewhat like the folded investment sheets of the earlier era (e.g., the type seen in Siptah's burial), covering the bodies and turned "back" (folded upon themselves) usually with left side flap coming in first with the right side overlapping it. ${ }^{40}$ Some of these are turned up at the ends or partly sewn up to hold and cushion the body within ( $\mathrm{N} 2000$ ), or folded above the body and secured by outer "bindings" (N 2001). They may be used singly ( $\mathrm{N} 2200$ ), but often occur in pairs or even in threes ( $\mathrm{N}$ 2003), although investment in four shawls ( $\mathrm{N}$ 2009) or even six shawls is also seen $(\mathrm{N} 2700){ }^{41}$

Use of 2-strand fiber cordage to bind bodies is much more widespread than in pharaonic times. This "tying up" is particularly noticeable in the exterior layers of investment where it is used to secure the wrapping shawls around the bodies. Outer binding can sometimes be exceedingly complex, if not elaborate or decorative. Cordage can form intersections that are artfully knotted to form taut lozenge-shaped lashings running along the body's central axis ( $\mathrm{N} 2004, \mathrm{~N} 2005, \mathrm{~N} 2009$; Fig. 11.4a). ${ }^{42}$ A related approach to lashing found at Naga ed-Deir N 2000/N 2500 may be called axial truss-pattern (Fig. 11.4b).43 It is sometimes found used to bind the inner wrapping shawl (N 2003). In other inner bindings, the approach is even simpler: ten or twelve transverse cords are sometimes passed around the body within its shawl, and these are often connected by just a few dispersed diagonal cords ( $\mathrm{N} 2416)$.

Clothing items (referred to as "shirts" within the notes) are the primary apparel worn, and in the vast majority of cases, the investment sheets ("wrapping

39 Lane [1860] $1908,5^{2-53}$. The hulaleeyah is described as woolen. It is a shawl wrapped around the shoulders.

40 A sheet of this type was also noted surrounding the bandaged mummy of Irethorrou (c. 5 Oо BCE) from Akhmim (Fine Arts Museums of San Francisco 42895). Irethorrou was laid upon the sheet, a tough linen fabric of thick strands, and its sides were pulled up around the body (Dreyfus and Elias, 2014, fig. 6). I suspect that this form of investment sheet was rather more common than is reflected in the literature.

The Naga ed-Deir notes concerning the wrapping shawls refer repeatedly to folding over "in the usual way"; a shawl in burial N 2002 was done differently, the right side described as having been "thrown over before the left".

41 In $\mathrm{N} \mathrm{2003}$, the third wrapping shawl is described as unfinished, as if removed from the loom to be added to this burial.

42 See NED-B-7868 from N 2009. A similar lashing pattern is used to secure a Coptic body found at Deir el-Bachit (western Thebes), but in it (SKB 5), decorative woven ribbons are used to do the tying (Lösch, Hower-Tillman, and Zink 2013, 34, fig. 5).

43 See NED-B-7904 from $\mathrm{N}$ 2003. The pattern resembles the structural truss used in iron bridge construction. 


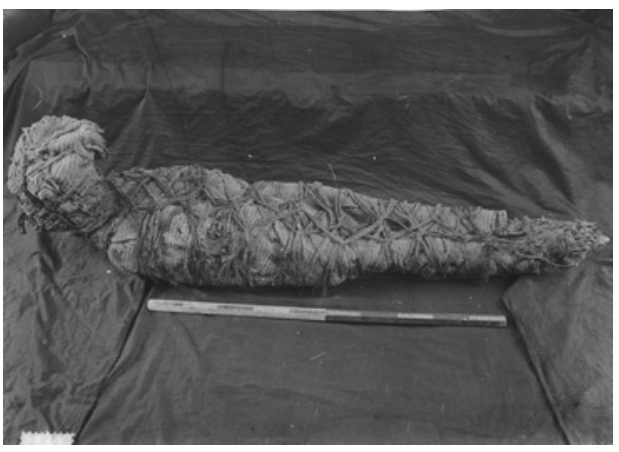

FIGURE $11.4 \mathrm{~A}$

Body from $\mathrm{N} 2009$ (as discovered) with axial lozenge-pattern lashing on the exterior (NED-B-7868)

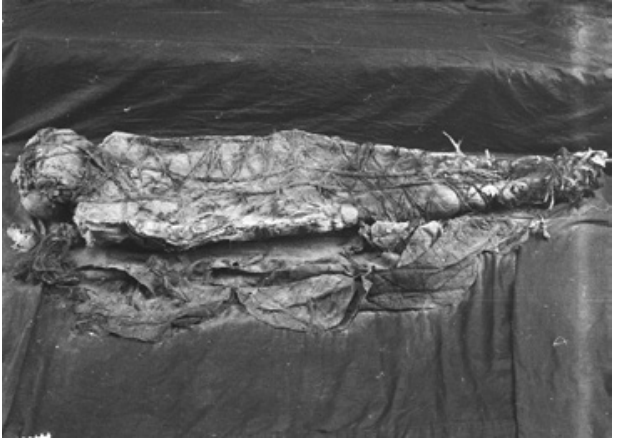

FIGURE 11.4B

Body from $\mathrm{N} 2003$ showing axial truss-pattern lashing under an external un-lashed sheet that has been removed (NED-B-79O4)

shawls" in the notes) are drawn up around them. It is not uncommon for a body to wear two or three shirts.

The way in which the bodies wear the shirts is extremely interesting, for arms being left out-of-the-sleeves is noted again and again. One case is the body in N 2001, where a "shirt with embroidered rosettes round (the) sleeves" was placed on the mummy but without the arms being put into the sleeves themselves. ${ }^{44}$ The significance of this practice is unknown, but leaving arms out-of-sleeve, so to speak, may be a deliberately non-quotidian gesture or sign of devotion akin to a priestly scapular. As far as the "old shirts" mentioned in the notes are concerned, many see service "opened-up" like sheets in which to enfold the body or, more often, rolled up as protection over the head, sometimes forming "an enormous pad of cloth" over the face. ${ }^{45}$ In $\mathrm{N} 2008$, a small shirt was used to wrap an infant child's feet.

Padding of the head and face is a vital distinguishing characteristic of Coptic funerary preparation. This is not confined to Naga ed-Deir, but has been seen at

44 Keeping the arms out-of-the-sleeves is not unusual at $\mathrm{N} 2000 / \mathrm{N} 2500$ and should be noted in any future excavations at Coptic sites.

$45 \quad \mathrm{~N} 2000, \mathrm{~N} 2001$. 


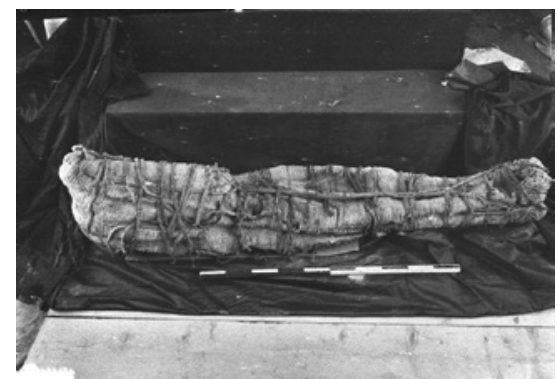

FIGURE 11.5A

Body from N 2416 before unwrapping (State 1) (NED-B-7089)

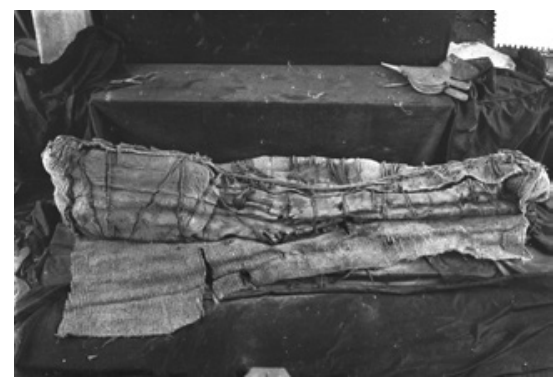

FIGURE $11.5 \mathrm{C}$

Body from N 2416, outer wrapping shawl pulled open (State 3) (NED-B-7O91)

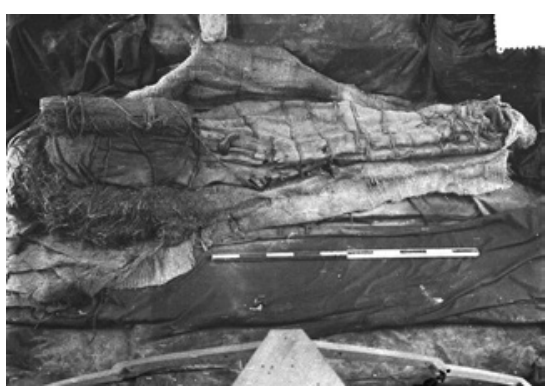

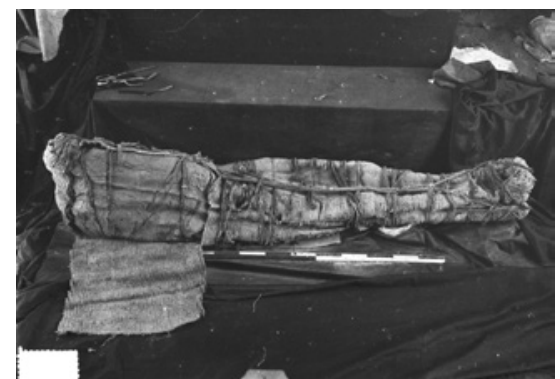

FIGURE 11.5B

Body from $\mathrm{N} 2416$, head bundle revealed (State 2) (NED-B-7O9O)

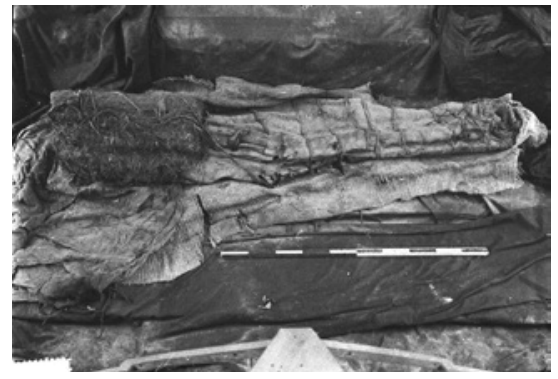

FIGURE 11.5D

Body from N 2416, head cloth pulled back, stuffing inside revealed (State 4) (NED-B-7O92)

FIGURE 11.5E

Body from N 2416, showing rolled fiber bundles on the head portion of the inner wrapping shawl (State 5) (NED-B-7093)

el-Hibeh and elsewhere. A large number of bodies show carefully rolled up cylinders made of grass or other vegetal fibers, secondarily wrapped in cloth and tied off ( $\mathrm{N}$ 2416). Body $\mathrm{N} 2416$ is a good example of just how much attention might be lavished on the head for protective or ritual purposes, as is shown in an unwrapping sequence captured in the original Naga ed-Deir season photos 


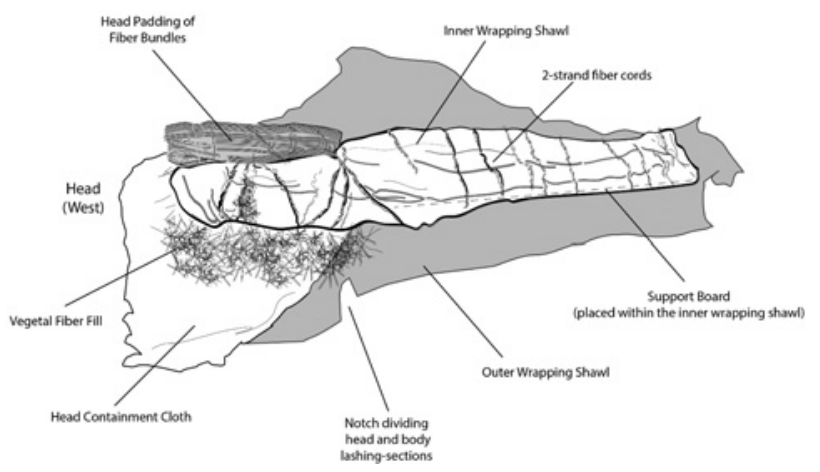

FIGURE 11.6 Diagram of the body in N 2416 showing its main wrapping features DRAWN BY J. ELIAS

(Figs. 11.5a-e). ${ }^{46} \mathrm{~A}$ system of five cylindrical bundles of tied grass is used. The bundles are grouped, then cushioned with loose fiber, and the whole mass is unified inside a fine cloth head shawl. The outer "wrapping shawl" is given a special notch to create a flap that allows it to more effectively cover the voluminously covered head. The major features are shown and labeled in Fig. 11.6.

Considering the age of the Naga ed-Deir burials, skeletal articulation is fairly high, and this shows that the approaches to wrapping found at this Christian site were sufficient to maintain bodily integrity for centuries after death. This effectively is a coincidental benefit of the community's adherence to a traditional and very ancient Egyptian respect toward physical remains. It shows a very understandable need to care for bodies through multitiered protective wrapping strategies and is far from the departure from body-centrism that St. Augustine would have preferred. The use of salt is important, but it is difficult to determine how much of it had been used as a chemical immersive as opposed to being added into the wrappings at time of burial. In many cases, seeds are found in connection with the salt, and it would be interesting to know if the excavators viewed the seeds as a symbol of fertility or as a practical additive. ${ }^{47}$ Although the excavation notes from N 2000/N 2500 do not mention fragrance impact in connection with any of the tombs, we must conclude that aromatic herbs were deliberately used or indirectly introduced in vegetal materials, like acacia, placed next to the bodies for other purposes. ${ }^{48}$ Nevertheless the saturation levels in the bodies are not very high.

46 The complete series is NED-B-7089-7093.

47 The particular species are not identified.

48 Acacia has resinous qualities. 
The limited scope of such applications seems to say something about Coptic "mummification" in the Naga ed-Deir/Deir el-Malak community and likely at Girga as well. ${ }^{49}$ It cannot be concluded on the basis of the available notes that $\mathrm{N} 2000 / \mathrm{N} 2500$ was a cemetery filled of impoverished souls. However, the effectiveness of soft tissue preservation afforded by the desiccation substances placed within the wrapping layers of the Naga ed-Deir bodies was not particularly high when compared with earlier methods or with some of the more elaborate strategies identified at other Coptic sites. $\mathrm{N} 2000 / \mathrm{N} 2500$ appears as a more conservative cemetery in this regard.

\section{Bibliography}

Bagnall, R. S. 1988. "An Early Christian Burial at Tell el-Maskhuta." ZPE 74:291-292.

Bagnall, R. S. 1993. Egypt in Late Antiquity. Princeton.

Bell, H. I. [1948] 1980. Egypt: From Alexander to the Arab Conquest, A Study in the Diffusion and Deca of Hellenism. Reprint. Chicago.

Bresciani, E. 1996. Il volto di Osiri. Tele funerary dipinte nell'Egitto romano (The Face of Osiris. Painted Funerary Shrouds in Roman Egypt). Translated by H. Adkins. Lucca.

Budge, E. A. W. 1894. The Mummy, Chapters on Egyptian Funereal Archaeology. 2nd ed. Cambridge.

Calmet, A. [1722] 1732. Dictionnaire historique, critique, chronologique, géographique et littéral de la Bible, vol. 2. Translated by S. D'Oyley and J. Colson. London.

Corcoran, L. 1997. "Mysticism and the Mummy Portraits." In Portraits and Masks: Burial Customs in Roman Egypt, edited by M. L. Bierbrier, 45-53. London.

Dreyfus, R. and J. Elias. Forthcoming. "Mummy by the Bay: Irethorrou, An Egyptian Priest of the Early Persian Period." In Gedenkschrift for Candy Keller. Also: www .academia.edu/38354340/Dreyfus_R._and_Elias_J__2014._Mummy_by_the_Bay _Irethorrou_An_Egyptian_Priest_of_the_Early_Persian_Period._Draft_of_an _article_accepted_for_publication_but_delayed and www.famsf.org/blog/mummy -bay-irethorrou-egyptian-priest-early-persian-period.

49 The community referred to had strong connections with Girga into recent times. Frederick Ludwig Norden's map of the stretch of the river taking in Akhmim and Naga ed-Deir (drawn 1738, published 1755) is labeled as follows: Deier Melac Chretiens de Tschirsch. (Girga). Although on the same side of the river as Akhmim, Naga ed-Deir was not under the jurisdiction of the Prince of Akhmim in Norden's day. 
Elias, J. 2007. "Preliminary CT Scan Analysis of an Egyptian Mummy in the Louisiana Art and Science Museum, Baton Rouge." AMSC Research Report, AMSC-16, Study 1. Carlisle.

Germer, R. 1997. Mummies: Life after Death in Ancient Egypt. Munich.

Girotti, M., K. Al-Hariri, S. Al-Khayem, R. Boano, S. Harter-Lailheugue, C. El-Bcheraoui, D. Chevé, E. Fulcheri, E. Massa, and G. Boëtsch. 2005. "The Mummies of the Archaeology Museum of Palmyra." Proceedings of the V World Congress on Mummy Studies, Journal of Biological Research 80: 262-267.

Goswami, S., K. Mishra, R. Singh, P. Singh, and P. Singh. 2016. "Sebania sesban, A Plant with Diverse Therapeutic Benefits: An Overview." SGVU Journal of Pharmaceutical Research \& Education 1:111-121.

Greenhill, T. 1705. Nekpokēdeia, or, The Art of Embalming. London.

Heikkinen, D. 2012. "The Influence of Christianity on Burial Practices in Middle Egypt from the Fourth to the Sixth Centuries." In Current Research in Egyptology 2011, edited by H. Abd El Gawad, N. Andrews, M. Correas-Amador, V. Tamorri, J. Taylor, 107-116. Oxford.

Ikram, S. 2015. "Bahariya Oasis: Valley of the Golden Mummies." In Mummies around the World: An Encyclopedia of Mummies in History, Religion, and Popular Culture, edited by M. Cardin, 19-21. Santa Barbara.

Lane, E. W. [186o] 1908. The Manners and Customs of the Modern Egyptians. London. Leca, A.-P. [1976] 1981. The Egyptian Way of Death: Mummies and the Cult of the Immortal. Translated by L. Asmal. Garden City.

Leveque, M. 2001. "Conservation Study of Mummy 1999.1.11." Report on file in the Michael C. Carlos Museum, Emory University, Atlanta.

Lösch, S., E. Hower-Tillman, and A. Zink. 2013. "Mummies and Skeletons from the Coptic Monastery Complex Deir-el-Bachit in Thebes-West, Egypt.” Anthropologischer Anzeiger 70/1: 27-41.

McNally, S. and I. Dvoržak Schrunk. 1993. Excavations in Akhmim Egypt: Continuity and Change in City Life from Late Antiquity to the Present. Oxford.

Nardius, I. 1647. Titi Lucretii Cari De Rerum Natura Libri Sex. Una cum Paraphrastica Explanatione \& Animadversionibus. Florence.

Norden, F. L. 1757. Travels in Egypt and Nubia. Translated by Peter Templeman. London.

Olearius, A. 1674. Gottorffische Kunst-Kammer, Worinnen Allerhand ungemeine Sachen, so theils die Natur, theils künstliche Hände hervor gebracht und bereitet. Schleswig.

Parlasca, K. 1997. "Mummy Portraits: Old and New Problems." In Portraits and Masks: Burial Customs in Roman Egypt, edited by M. L. Bierbrier, 127-13o. London.

Petrie, W. M. F. 1911. Roman Portraits and Memphis (IV). London.

Pollès, R. 2001. La Momie de Khéops à Hollywood. Paris. 
Pommerening, T. 2010. "Mummies, Mummification Techniques and the Cult of the Dead in Ancient Egypt-A Chronological Overview." In Mummies of the World, edited by A. Wieczorek and W. Rosendahl, 74-91. Munich.

Reisner, G. A. 19o8. The Early Dynastic Cemeteries of Naga-ed-Dêr, Part I. Leipzig.

Richardin, P., M. Coudert, N. Gandolfo, and J. Vincent. 2013. "Radiocarbon Dating of Mummified Human Remains: Application to a Series of Coptic Mummies from the Louvre Museum." Proceedings of the 21st International Radiocarbon Conference, Radiocarbon 55: 345-352.

Riggs, C. 2005. The Beautiful Burial in Roman Egypt: Art, Identity, and Funerary Religion. Oxford.

Schulz, R. 1998. "Travelers, Correspondents, and Scholars: Images of Egypt through the Millennia." In Egypt The World of the Pharaohs, edited by R. Schulz and M. Seidel, 491-497. Cologne.

Śliwa, J. 2006. "Andreas Gryphius und Giovanni Nardi." In Aegyptus et Pannonia III, edited by H. Gyory, 247-259. Budapest.

Smith, G. E. [1912] 200o. The Royal Mummies. London.

Smith, G. E. and W. R. Dawson. 1924. Egyptian Mummies. London.

Taylor, J. H. 2001. Death and the Afterlife in Ancient Egypt. Chicago.

Wade, A. D., B. Lawson, D. Tampieri, and A. J. Nelson. 2014. "Hybrid Ritual: Abdominal Incision Plate Use in a Case of Transperineal Evisceration." Yearbook of Mummy Studies 2:103-108.

Willeitner, J. 1998. “Tomb and Burial Customs after Alexander the Great.” In Egypt: The World of the Pharaohs, edited by R. Schulz and M. Seidel, 313-321. Cologne.

Yohe, R. M., J. Gardner, and D. Heikkinen. 2005. "A Preliminary Analysis of Mummies NGLP-7 and NGLP-8 from the North Gate Looter Pit, Tell El-Hibeh, Middle Egypt 2005 Field Season." Report on File at the Archaeological Research Center, Cairo. 